\title{
Nitrous oxide emission budgets and land-use-driven hotspots for organic soils in Europe
}

\author{
T. Leppelt ${ }^{1}$, R. Dechow ${ }^{1}$, S. Gebbert ${ }^{1}$, A. Freibauer ${ }^{1}$, A. Lohila ${ }^{2}$, J. Augustin ${ }^{3}$, M. Drösler ${ }^{4}$, S. Fiedler $^{5}$, S. Glatzel ${ }^{6}$, \\ H. Höper ${ }^{7}$, J. Järveoja ${ }^{8}$, P. E. Lærke ${ }^{9}$, M. Maljanen ${ }^{10}$, ̈̈. Mander $^{8}$, P. Mäkiranta ${ }^{11}$, K. Minkkinen ${ }^{12}$, P. Ojanen ${ }^{12}$, \\ K. Regina $^{13}$, and M. Strömgren ${ }^{14}$ \\ ${ }^{1}$ Thünen Institute of Climate-Smart Agriculture, Braunschweig, Germany \\ ${ }^{2}$ Finnish Meteorological Institute, Helsinki, Finland \\ ${ }^{3}$ Leibniz Centre for Agricultural Landscape Research, Müncheberg, Germany \\ ${ }^{4}$ Weihenstephan-Triesdorf University of Applied Sciences, Freising, Germany \\ ${ }^{5}$ Johannes Gutenberg University, Mainz, Germany \\ ${ }^{6}$ University of Vienna, Vienna, Austria \\ ${ }^{7}$ LBEG State Authority for Mining, Energy and Geology, Hannover, Germany \\ ${ }^{8}$ University of Tartu, Tartu, Estonia \\ ${ }^{9}$ Aarhus University, Department of Agroecology, Tjele, Denmark \\ ${ }^{10}$ University of Eastern Finland, Kuopio, Finland \\ ${ }^{11}$ Finnish Forest Research Institute, Vantaa, Finland \\ ${ }^{12}$ University of Helsinki, Department of Forest Sciences, Helsinki, Finland \\ ${ }^{13}$ MTT Agrifood Research Finland, Jokioinen, Finland \\ ${ }^{14}$ Swedish University of Agricultural Sciences, Uppsala, Sweden
}

Correspondence to: T. Leppelt (thomas.leppelt@ti.bund.de)

Received: 7 May 2014 - Published in Biogeosciences Discuss.: 16 June 2014

Revised: 15 October 2014 - Accepted: 19 October 2014 - Published: 1 December 2014

\begin{abstract}
Organic soils are a main source of direct emissions of nitrous oxide $\left(\mathrm{N}_{2} \mathrm{O}\right)$, an important greenhouse gas (GHG). Observed $\mathrm{N}_{2} \mathrm{O}$ emissions from organic soils are highly variable in space and time, which causes high uncertainties in national emission inventories. Those uncertainties could be reduced when relating the upscaling process to a priori-identified key drivers by using available $\mathrm{N}_{2} \mathrm{O}$ observations from plot scale in empirical approaches. We used the empirical fuzzy modelling approach MODE to identify main drivers for $\mathrm{N}_{2} \mathrm{O}$ and utilize them to predict the spatial emission pattern of European organic soils. We conducted a meta-study with a total amount of 659 annual $\mathrm{N}_{2} \mathrm{O}$ measurements, which was used to derive separate models for different land use types. We applied our models to available, spatially explicit input driver maps to upscale $\mathrm{N}_{2} \mathrm{O}$ emissions at European level and compared the inventory with recently published IPCC emission factors. The final statistical models explained up to $60 \%$ of the $\mathrm{N}_{2} \mathrm{O}$ variance. Our study re-
\end{abstract}

sults showed that cropland and grasslands emitted the highest $\mathrm{N}_{2} \mathrm{O}$ fluxes $0.98 \pm 1.08$ and $0.58 \pm 1.03 \mathrm{~g} \mathrm{~N}_{2} \mathrm{O}-\mathrm{N} \mathrm{m}^{-2} \mathrm{a}^{-1}$, respectively. High fluxes from cropland sites were mainly controlled by low soil $\mathrm{pH}$ value and deep-drained groundwater tables. Grassland hotspot emissions were strongly related to high amount of $\mathrm{N}$-fertilizer inputs and warmer winter temperatures. In contrast, $\mathrm{N}_{2} \mathrm{O}$ fluxes from natural peatlands were predominantly low $\left(0.07 \pm 0.27 \mathrm{~g} \mathrm{~N}_{2} \mathrm{O}-\mathrm{N} \mathrm{m}^{-2} \mathrm{a}^{-1}\right)$ and we found no relationship with the tested drivers. The total inventory for direct $\mathrm{N}_{2} \mathrm{O}$ emissions from organic soils in Europe amount up to $149.5 \mathrm{Gg} \mathrm{N}_{2} \mathrm{O}-\mathrm{Na}^{-1}$, which also included fluxes from forest and peat extraction sites and exceeds the inventory calculated by IPCC emission factors of $87.4 \mathrm{Gg} \mathrm{N}_{2} \mathrm{O}-\mathrm{Na}^{-1} . \mathrm{N}_{2} \mathrm{O}$ emissions from organic soils represent up to $13 \%$ of total European $\mathrm{N}_{2} \mathrm{O}$ emissions reported in the European Union (EU) greenhouse gas inventory of 2011 from only $7 \%$ of the EU area. Thereby the model demonstrated that the major part $(85 \%)$ of the inventory 
is induced by anthropogenic management, which shows the significant reduction potential by rewetting and extensification of agriculturally used peat soils.

\section{Introduction}

Nitrous oxide $\left(\mathrm{N}_{2} \mathrm{O}\right)$ is a natural trace gas with increasing abundance in the atmosphere and radiation-enforcing properties. Soil processes are the dominant source of terrestrial $\mathrm{N}_{2} \mathrm{O}$ and contribute about $70 \%$ to the total net emission budget of $\mathrm{N}_{2} \mathrm{O}$ (Mosier, 1998). Maljanen et al. (2010) showed that $\mathrm{N}_{2} \mathrm{O}$ emissions from organic soils in Nordic countries are 4 times higher in comparison to fluxes from mineral soils. In Europe about $7 \%$ of the land area is covered by organic soils, often also called peat soils, according to Montanarella et al. (2006). The $\mathrm{N}_{2} \mathrm{O}$ fluxes from natural, waterlogged organic soils are low. Drainage and cultivation lead to $\mathrm{N}$ mineralization from degrading peat, and consequently $\mathrm{N}_{2} \mathrm{O}$ production (Wild et al., 1998; Regina et al., 2004) via nitrification and denitrification processes (Firestone and Davidson, 1989). Thus far, large-scale estimates have been based on static emission factor approaches, which only partly reflect land use, climate, soil nutrient or drainage status. A regional study from Estonia found significant land use differences in $\mathrm{N}_{2} \mathrm{O}$ emissions from drained organic soils (Mander et al., 2010). The IPCC recently published new emission factors for different land use types, climate regions and basic soil nutrient and drainage categories for global application in the IPCC supplement for national greenhouse gas (GHG) inventories on wetlands (IPCC, 2013). Application of emission factors in GHG inventories can lead to high uncertainties (Pouliot et al., 2012). At present, there are no process-based models of $\mathrm{N}_{2} \mathrm{O}$ fluxes for organic soils that could be upscaled or explain the variability of measured $\mathrm{N}_{2} \mathrm{O}$ fluxes from European peatlands better than average emission factors. A successful upscaling of an empirical model could reduce the uncertainty of emission budgets by including functional relationships to driving parameters. Klemedtsson et al. (2005) suggested to model $\mathrm{N}_{2} \mathrm{O}$ emissions from peatland forest in Sweden with an empirical relationship to $\mathrm{C} / \mathrm{N}$ ratio of topsoil, based on observations from 12 sites. In Great Britain, $\mathrm{N}_{2} \mathrm{O}$ emissions from agricultural organic soils were modelled with a regression to $\mathrm{N}$ input, water-filled pore space (WFPS), soil temperature and land use (Sozanska et al., 2002), based on observations from 59 sites predominantly from mineral soils. The long reference lists in the 2013 IPCC supplement suggest that there are a large amount of $\mathrm{N}_{2} \mathrm{O}$ observations in the literature that have not yet been used for model calibration and validation. While some region- and land-use-specific empirical relationships have been published (Klemedtsson et al., 2005; Mander et al., 2010), a generic functional relationship between $\mathrm{N}_{2} \mathrm{O}$ and environmental and management drivers across land use categories is missing. This hampers the development of man- agement strategies at local, national and European scale for organic soils that reduce anthropogenic $\mathrm{N}_{2} \mathrm{O}$ emissions. This study aims to

1. develop generic empirical relationships between human and natural drivers of $\mathrm{N}_{2} \mathrm{O}$ applicable across land use types by means of multi-site calibration with all observations published until mid-2013 in Europe;

2. determine the $\mathrm{N}_{2} \mathrm{O}$ budget of organic soils in Europe and its various sources of uncertainty (model, spatial driver data);

3. determine spatial hotspots of $\mathrm{N}_{2} \mathrm{O}$ emissions driven by land use, other human or natural drivers and priorities for future observations in high- $\mathrm{N}_{2} \mathrm{O}$-risk zones;

4. test whether the new IPCC emission factors are spatially representative of Europe and quantify potential bias.

\section{Material and methods}

\subsection{Database}

The $\mathrm{N}_{2} \mathrm{O}$ flux synthesis is based on a meta-study of direct $\mathrm{N}_{2} \mathrm{O}$ emissions from organic soils. This literature survey contains $\mathrm{N}_{2} \mathrm{O}$ observations in Europe published until mid-2013. All incorporated in situ flux measurement studies used the same gas measurement method - the well-established closedchamber technique (Hutchinson and Mosier, 1981). Annual $\mathrm{N}_{2} \mathrm{O}$ fluxes were directly taken out of the publications and all fluxes that fulfil the minimum criteria of 12 measurements per year were included in our analysis. The database contains the total amount of 659 annual flux measurements made on 109 sites in temperate and boreal regions in Europe, spread across the main organic soil regions (Fig. 1). Numerous measurements came from central Europe (Germany, Netherlands) and from northern European countries like Finland, Sweden and Estonia, whereas the British Isles and eastern and southern Europe are under-represented in the dataset. The number of measurements per site differs from a minimum of 1 annual flux period up to a total amount of 59 annual fluxes. Most of the sites include flux measurements from different plots that vary in management and environmental conditions. In part, the experimental design was purposely chosen to distinguish between treatments or influences from different sources, e.g. nitrogen fertilizer (Velthof and Oenema, 1995) or water content of topsoil (van Beek et al., 2010). We extracted diverse environmental and management parameters to derive a wide set of parameters that can be tested for potential relationships to $\mathrm{N}_{2} \mathrm{O}$ fluxes. The most frequent parameters are listed in Table 1 with units, parameter ranges and fraction of coverage in the studies. Missing values for climate parameters were gap-filled with data from the European Climate Assessment and Dataset (ECAD), described 
Table 1. List of potential driving parameters for $\mathrm{N}_{2} \mathrm{O}$ with units, value mean/range and fraction of measurement studies that cover each parameter. Soil parameters are related to topsoil layer of $100 \mathrm{~cm}$ depth and all parameters are calculated as annual average values, with the exception of precipitation and nitrogen fertilization, which are calculated as annual sums.

\begin{tabular}{llrrrrr}
\hline Name & Description & Unit & Mean & Min & $\begin{array}{r}\text { Max } \\
\text { Fraction } \\
(\%)\end{array}$ \\
\hline bd & Bulk density & $\mathrm{g} \times \mathrm{cm}^{-3}$ & 0.34 & 0.03 & 1.36 & 69.2 \\
corg & Organic carbon content & $\%$ & 36.11 & 6.7 & 57.5 & 79.8 \\
ntot & Total nitrogen content & $\%$ & 1.82 & 0.3 & 3.9 & 71.8 \\
ph & pH value & - & 5.34 & 3.3 & 7.63 & 61 \\
cn & Ratio of carbon and nitrogen & - & 21.29 & 9 & 78.17 & 80.4 \\
pd & Thickness of peat layer & $\mathrm{m}$ & 1.61 & 0.2 & 10.2 & 38.7 \\
tair & Air temperature & ${ }^{\circ} \mathrm{C}$ & 6.22 & -0.23 & 11.2 & 83.5 \\
tsoil & Soil temperature & ${ }^{\circ} \mathrm{C}$ & 8.8 & 1.94 & 11.78 & 19.1 \\
pp & Precipitation & $\mathrm{mm}$ & 645.2 & 0 & 1840 & 81.6 \\
wt & Groundwater table & $\mathrm{m}$ & 0.32 & -0.62 & 1.36 & 82.2 \\
wfps & Water-filled pore space & $\%$ & 76.48 & 41.25 & 100 & 13.7 \\
no3 & Nitrate concentration & $\mathrm{kg} \times \mathrm{ha}^{-1}$ & 32.97 & 0 & 211.7 & 13.1 \\
nh4 & Ammonia concentration & $\mathrm{kg} \times \mathrm{ha}^{-1}$ & 28.4 & 0.33 & 241 & 13.1 \\
nmin & Mineral nitrogen concentration & $\mathrm{kg} \times \mathrm{ha}^{-1}$ & 61.37 & 2.21 & 241 & 14.3 \\
nfert & Organic and mineral nitrogen fertilization & $\mathrm{kg} \times \mathrm{ha}^{-1}$ & 43.77 & 0 & 713 & 80.7 \\
\hline
\end{tabular}

in Haylock et al. (2008). All of the database references are listed in Table 6 .

\subsection{Model development, calibration and validation}

Firstly, the $\mathrm{N}_{2} \mathrm{O}$ fluxes and potential drivers were analysed by means of univariate statistics. Furthermore we investigated the correlations between fluxes and the corresponding driving parameters to understand interactions and constrain parameter combinations. The specified statistical analyses were carried out with the programming language $R(R$ Development Core Team, 2013). Based on these results we used an empirical fuzzy logic modelling approach to predict $\mathrm{N}_{2} \mathrm{O}$ fluxes based on main driving parameters. This datadriven fuzzy logic model has been applied to predict and upscale annual $\mathrm{N}_{2} \mathrm{O}$ fluxes for agricultural mineral soils in Germany. The model performance was superior to other empirical approaches and explained up to $72 \%$ of the variability in the dataset. (Dechow and Freibauer, 2011). Bardossy et al. (2003) describe the fuzzy-based modelling as a fast, transparent and parameter-parsimonious alternative to other approaches. These techniques are based on the concept of fuzzy logic, a set theory that extends the binary logic of true (1) and false (0). It allows for fuzzy sets with truth values in the range between 0 and 1 (degree of fulfilment) to be had, and is therefore able to handle partial truth, uncertainties or so-called fuzziness. The fuzzy sets can be used to classify factor domains not only by constant crisp sets but also by different function types (e.g. triangular, quadratic) with variable membership grade over the factor domain. Furthermore it can be utilized to divide factor spaces into sub-domains and calculate all possible combinations in fuzzy interference schemes (FISs) using fuzzy logic algebra. These FISs can be merged in conditional rule systems to model multivariate problems. The approach is able to model non-linear relationships and to represent a priori knowledge that limits parameter spaces or constrains directions of relationships. Another advantage of fuzzy sets in comparison to other decision tree approaches is the smooth transition between different sets that allows for more accurate modelling of continuous variables. In this study triangular fuzzy sets for driving parameters of annual $\mathrm{N}_{2} \mathrm{O}$ fluxes were calibrated using a simulated annealing technique to optimize corresponding responses for $\mathrm{N}_{2} \mathrm{O}$ flux measurements. We use a forward selection algorithm in combination with a sub-dataset, which consists of drivers that are available at European level, to determine the best-fitted and regionalizable parameter combinations. The Nash-Sutcliffe efficiency (NSE) was used for model assessment:

$\mathrm{NSE}=1-\frac{\sum_{i=1}^{n}\left(F_{\mathrm{o}}^{i}-F_{\mathrm{m}}^{i}\right)^{2}}{\sum_{i=1}^{n}\left(F_{\mathrm{o}}^{i}-\bar{F}_{\mathrm{o}}\right)^{2}}$.

The coefficient ranges from $-\infty$ to 1 , where the value of 1 corresponds to a perfect match and a value of 0 indicates an accuracy comparable to the mean of the observed data. The residual variance of the observed fluxes $F_{\mathrm{o}}^{i}$ and the modelled fluxes $F_{\mathrm{m}}^{i}$ must be smaller than the data variance of the observed fluxes to indicate that the model is a better predictor than the mean value of the observed data $\bar{F}_{\mathrm{o}}$. The NSE coefficient is described as a good indicator of model prediction performance because it is a combined measure for scatter and bias (Nash and Sutcliffe, 1970). The 


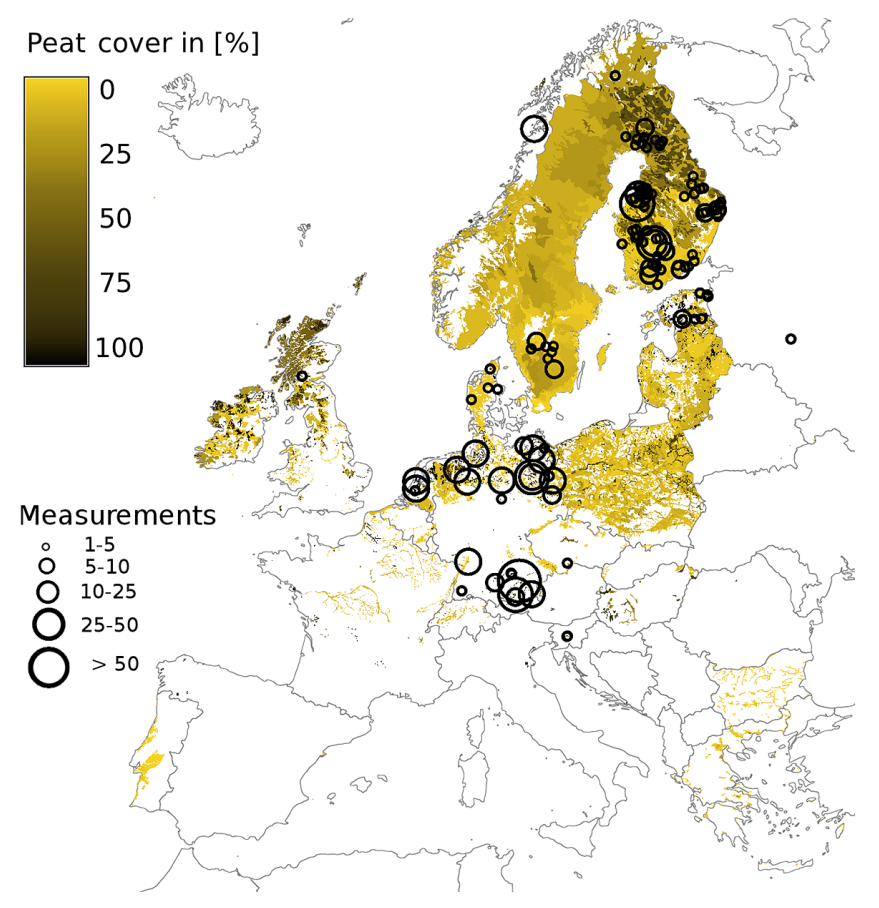

Figure 1. Overview for measurement sites. Size of points indicates number of measurements per site. Background map displays peatland distribution in Europe with peat cover per square kilometre from Montanarella et al. (2006).

automaticallyselectedparameter combinations with the highest NSE measures above 0 represent the best $\mathrm{N}_{2} \mathrm{O}$ predictors according to the parameter set and performance indicator used. The $\mathrm{NSE}_{\text {cali }}$ and $\mathrm{NSE}_{\mathrm{cv}}$ refer to the NSE coefficient for the model calibration and the validation, respectively.

Further optimization was performed by setting up model ensembles (MODE) for final parameter combinations, using empirical bootstrapping methods with up to 50 individual models, which reduces over-fitting and achieves better averaged model predictions. We followed the procedures described in Dechow and Freibauer (2011).

We validated the model results by a $k$-fold cross validation by study sites (Kohavi, 1995). The original dataset was partitioned into $k$ subsets by study site. A single subsample was excluded as a validation dataset from the calibration process. All remaining $k-1$ sites were used for model calibration and could be validated to the independent validation set. This procedure is repeated $k$ times until each site is used once as a validation dataset. The study sites subsamples include a different number of annual fluxes, which can contain up to $15 \%$ of the fluxes from the total dataset. Hence the unequally sized subsamples can lead to a very strict cross-validation result in the case of excluding a site with numerous measurements and high proportion of the total dataset. The calibration was weighted by number of measurements per site to avoid overand under-representation for sites with small and high numbers of flux measurements, respectively. We also have to take into account that the $\mathrm{N}_{2} \mathrm{O}$ fluxes span over several orders of magnitude. Hence we applied a logarithmic transformation,

$F_{\mathrm{o}}^{l}=\ln \left(F_{\mathrm{o}}^{i}+0.5\right)$,

to linearize the flux range for better optimization performance. To generate models useful for upscaling, we considered only driving parameters that can be regionalized. Therefore good predictors of $\mathrm{N}_{2} \mathrm{O}$ fluxes like soil nitrate $\left(\mathrm{NO}_{3}^{-}\right)$, ammonium $\left(\mathrm{NH}_{4}^{+}\right)$, mineral $\mathrm{N}$ content or $\mathrm{CN}$ ratio were not included in the final modelling approach.

\subsection{Regionalization}

The regionalization describes the application of our validated fuzzy model on EU-wide available input datasets to derive consistent $\mathrm{N}_{2} \mathrm{O}$ emissions for Europe. Spatially explicit upscaling of the fuzzy model was realized in a geographic information system (GIS). We used the open source GRASS GIS (Neteler et al., 2012) to process the model input datasets and predict $\mathrm{N}_{2} \mathrm{O}$ emissions at the EU level. Therefore we developed and implemented several GRASS modules to perform fuzzy logic modelling in this GIS framework. Additionally we conduct time series analysis of climate and land use data by using the temporal framework TGRASS (Gebbert and Pebesma, 2014). The input data at the EU level is predominantly available in raster cell format in Lambert azimuthal equal area (LAEA) projection, with the finest resolution of $1 \mathrm{~km} \times 1 \mathrm{~km}$ gridded data. Hence we selected the LAEA projection and a resolution of $1 \mathrm{~km} \times 1 \mathrm{~km}$ as a common unit to avoid data loss from transformation processes and raster cell resampling. The model was applied for peatland areas in $\mathrm{Eu}-$ rope which are based on the organic soil distribution map by Montanarella et al. (2006). This dataset serves as a basis for all spatial calculations in this study. The following regional datasets were used for driving parameters:

- Land use distribution:

- CORINE land cover (CLC) from 2006 (Büttner and Kosztra, 2007) differentiated into cropland, grassland, forest, peat extraction and natural areas.

- Historic Land Dynamics Assessment (HILDA) (Fuchs et al., 2013) differentiated into cropland, grassland (which also contains natural areas) and forest sites for the latest available year: 2010.

- Meteorology: temperature and precipitation from the ECAD dataset (Haylock et al., 2008). Based on the daily resolution dataset, we calculated the 30-year (1982-2012) long-term annual and seasonal (spring, summer, autumn and winter) minimal, maximal and mean temperatures and precipitations sums.

- Mean annual water table: there are no spatially explicit data available for Europe. Mean annual water table was therefore represented by land-use-specific frequency distribution functions of observed water table in 
the database. The mean value of the frequency distributions was used for regionalization, while the distribution served for uncertainty assessment.

- Soil properties: datasets from the European soil portal and the Joint Research Centre (JRC) (Panagos et al., 2012).

- Topsoil acidity (Reuter et al., 2008).

- Organic carbon content of topsoil (Jones et al., 2005).

- Bulk density of topsoil (Tiktak et al., 2002). The European soil portal provides gridded averages, which mix mineral and organic soils. Consequently, bulk density neither adequately reflects organic soils nor the dependence of bulk density on land use and peat degradation status. As for mean annual water table, land-use-specific frequency distribution functions of bulk density were used for regionalization.

- Nitrogen fertilization based on Hutchings et al. (2012).

The sum of Europe-wide annual $\mathrm{N}_{2} \mathrm{O}$ emissions represents the emissions from cropland, grassland, forest, peat extraction and natural sites on organic soils. Besides the fuzzy model approach, land-use-stratified emission factors can also be utilized to predict annual emission budgets. Emission factors were derived from the $\mathrm{N}_{2} \mathrm{O}$ flux synthesis as mean per land use type and compared to the IPCC emission factors from the wetland supplement (IPCC, 2013). We used the good practice guidance of the IPCC tier 1 approach to calculate the European inventory of $\mathrm{N}_{2} \mathrm{O}$ emissions from managed organic soils. The IPCC tier 1 approach stratifies land use classes by drainage, peat type and climate zone. The delineation between the temperate and boreal zone can be derived from the IPCC definition applied to climate data. Drainage and peat type, however, are not available in a spatially explicit way. We therefore applied the default of nutrient-poor conditions in boreal forests, nutrient-rich conditions in temperate forests, and deep drainage in temperate grasslands. Spatial resolution and land use definitions produce significant uncertainty in the regionalization of $\mathrm{N}_{2} \mathrm{O}$ emissions. The uncertainty in land use classifications was assessed by testing the sensitivity of the European $\mathrm{N}_{2} \mathrm{O}$ inventory to the choice of the land use map, represented by the two Europe-wide spatially explicit map products CORINE and HILDA. The general land use distribution on organic soils can be separated into the forestry-dominated boreal zone, the agricultural temperate zone and the main natural peatland areas in the subarctic northern parts of Europe. $\mathrm{N}_{2} \mathrm{O}$ emission hotspots were identified on the map together with related ranges of drivers separately for each land-use-specific model. In order to locate $\mathrm{N}_{2} \mathrm{O}$ emission hotspots in Europe, we computed the flux distributions by land use category from the $\mathrm{N}_{2} \mathrm{O}$ emission map and defined the fluxes above the 90th quantile as hotspot emissions for the particular land use category.

\subsection{Uncertainty analysis}

$\mathrm{N}_{2} \mathrm{O}$ emissions can vary largely in space and time and the capabilities to model these variation are restricted to the size of the sample dataset and the data quality. Therefore it is important to propagate the uncertainties during the modelling process in order to be able to estimate the overall accuracy of the model result. For several ecosystems the confidence interval limits of IPCC emission factors for $\mathrm{N}_{2} \mathrm{O}$ emissions from peat soils are greater than the mean values. The modelling approach aims to reduce this variability by using explanatory parameters to predict $\mathrm{N}_{2} \mathrm{O}$ fluxes. Uncertainty analysis comprised uncertainties in input parameters and in the model. The model uncertainty was calculated by means of a fuzzy rule-based uncertainty estimation (details in Dechow and Freibauer (2011)). It can be described as the standard deviation $\sigma_{\mathrm{f}}$, which is derived from the rule-specific normallike uncertainty distributions in Eq. (3):

$\sigma_{\mathrm{f}}^{2}=\frac{\sum_{i=1}^{n} \mathrm{DOF}_{i} \sigma_{\mathrm{r}_{i}}^{2}}{\sum_{i=1}^{n} \mathrm{DOF}_{i}}$

where $\mathrm{DOF}_{i}$ is the degree of fulfilment and $\sigma_{\mathrm{r}_{i}}$ is the standard deviation of a normal-like uncertainty distribution of rule $i$. The rule specific uncertainty was estimated by using results from the cross validation over study sites as a reference to calculate the model uncertainty. The input parameter uncertainties were estimated by Monte Carlo simulation with parameter variabilities taken from available databases. The combination of input and model uncertainty results in the overall uncertainty estimation, which was applied pixel-wise for uncertainty analysis at the EU level. The resulting map contains average and standard deviation values for a normallike distribution function of $\mathrm{N}_{2} \mathrm{O}$ emissions for each raster cell.

The $\mathrm{N}_{2} \mathrm{O}$ emission budget is the sum of all raster cell values that are located within a defined area. The corresponding uncertainty of the inventory can be calculated by error propagation. Spatially explicit modelling introduces autocorrelation into the calculation of GHG emission inventories and their uncertainty estimation. Without consideration of the spatial covariance we would underestimate the real uncertainty. This is a methodical problem that we solved by considering the covariance in the error propagation equation to improve the uncertainty estimation:

$$
\sigma_{\mathrm{b}}=\sqrt{\sum_{i=1}^{n} \sigma_{\mathrm{f}_{i}}^{2}+2 \sum_{i=1}^{n-1} \sum_{j=i+1}^{n} \operatorname{cov}_{i j}},
$$

where $\sigma_{i, j}$ is the standard deviation of a raster cell, indexed by $i$, and $\operatorname{cov}_{i j}$ is the corresponding covariance between all 

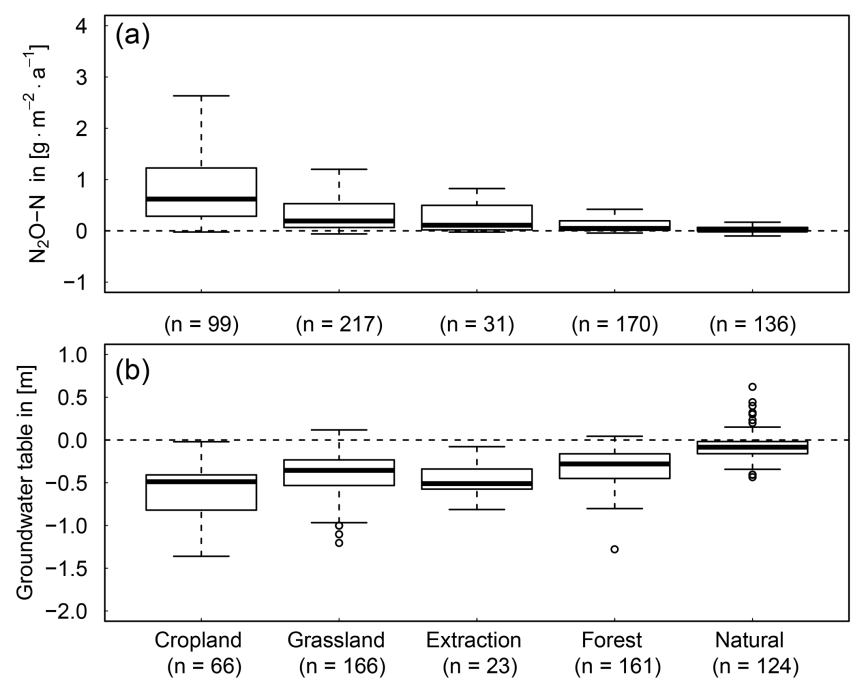

Figure 2. Box plots for $\mathrm{N}_{2} \mathrm{O}$ fluxes (a) and mean annual groundwater table (b) for five different land use categories (cropland, grassland, peat extraction, forest and natural sites). $\mathrm{N}_{2} \mathrm{O}$ fluxes are shown without outliers and $n$ indicates the number of measurement per category.

raster cell values, indexed by $i$ and $j$. We approximated the covariances between raster cells as a function of distance and calculated the corresponding covariance matrix to apply Eq. (4) to the raster map.

\section{Results and discussion}

\subsection{Statistical analysis}

The $\mathrm{N}_{2} \mathrm{O}$ fluxes were log-normal-distributed with predominantly minor fluxes between -0.1 and 0.1 and few high peaks up to $8.11 \mathrm{~g} \mathrm{~N}_{2} \mathrm{O}-\mathrm{N} \mathrm{m}^{-2} \mathrm{a}^{-1}$ from grasslands in the Netherlands (Koops et al., 1997). We found significant differences in flux data between land use categories; these are shown in Fig. 2. In general the highest fluxes occurred on cropland and grassland sites, whereas natural and rewetted organic soils feature low emissions on average. Fluxes from forest sites were on average lower than the emissions from cropland and grasslands, but included some high outliers of up to $6.06 \mathrm{~g} \mathrm{~N}_{2} \mathrm{O}-\mathrm{N} \mathrm{m}^{-2} \mathrm{a}^{-1}$ from Slovenia (Danevčič et al., 2010). The peat extractions sites were only represented by 35 annual flux measurements, which indicated an average flux of $0.47 \mathrm{~g} \mathrm{~N}_{2} \mathrm{O}-\mathrm{N} \mathrm{m}^{-2} \mathrm{a}^{-1}$ for active and abandoned extraction sites. Table 2 lists the correlation coefficients for $\mathrm{N}_{2} \mathrm{O}$ fluxes and main driving parameters. The mean annual groundwater tables for different land use categories were correlated to $\mathrm{N}_{2} \mathrm{O}$ fluxes with a correlation coefficient of $r=0.32(p<0.05)$. In addition, Fig. 3a shows that high $\mathrm{N}_{2} \mathrm{O}$ fluxes occurred in the range of mean groundwater table of 0.2 to $0.9 \mathrm{~m}$ below the surface. The groundwater table has been found to be a driving parameter for $\mathrm{N}_{2} \mathrm{O}$ in sev-
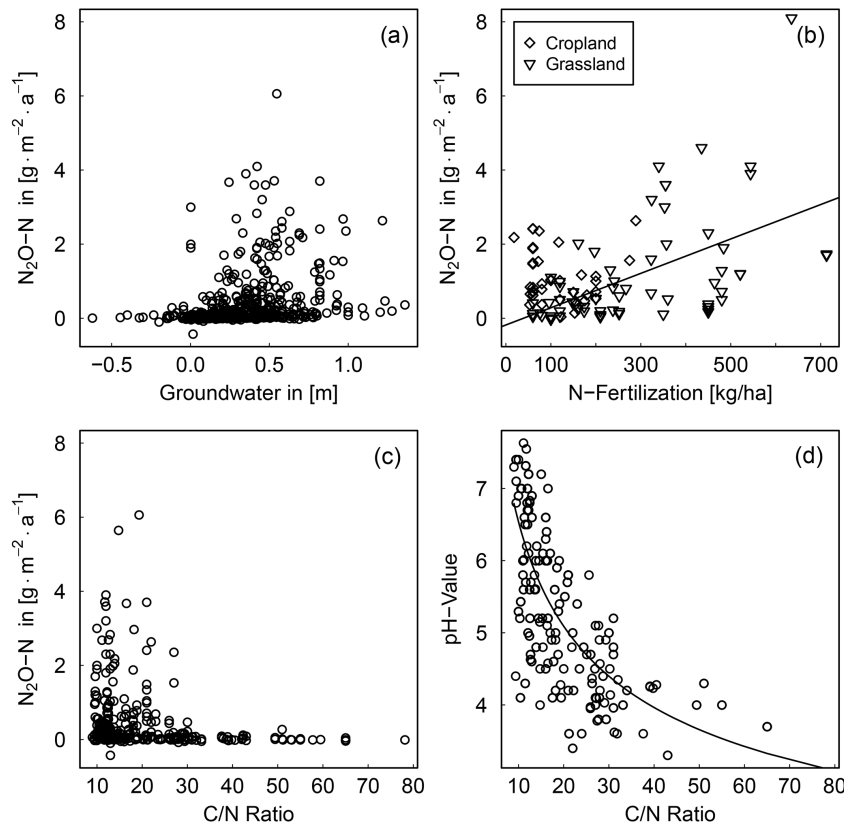

Figure 3. The scatter plots show (a) the $\mathrm{N}_{2} \mathrm{O}$ flux relationship to mean annual groundwater table, (b) the relationship between $\mathrm{N}$ fertilization and $\mathrm{N}_{2} \mathrm{O}$ fluxes for crop- and grassland with significant $(P<0.001)$ linear relationship for grassland $\left(r^{2}=0.26\right)$, (c) the $\mathrm{N}_{2} \mathrm{O}$ fluxes plotted against the $\mathrm{C} / \mathrm{N}$ ratios, and (d) $\mathrm{pH}$ values in relation to these $\mathrm{C} / \mathrm{N}$ ratios including the fitted non-linear function $\left(\mathrm{ph}=15 \mathrm{cn}^{-0.36}\right)\left(r^{2}=0.5\right)$.

eral other studies (Martikainen et al., 1993; Regina et al., 1996; van Beek et al., 2010). Drainage increases emissions of $\mathrm{N}_{2} \mathrm{O}$, in particular for nutrient-rich organic soils and fertilized and grazed grassland. The seasonal fluctuations of the water table could explain more variability of $\mathrm{N}_{2} \mathrm{O}$ emissions, but this information was only available for a small fraction of the dataset. Therefore we were restricted to the use of only the mean annual water table in our analysis. The $\mathrm{N}$-fertilization amount was also correlated with $\mathrm{N}_{2} \mathrm{O}$ fluxes $(r=0.43, p<0.05)$. Figure $3 \mathrm{~b}$ suggests that this relationship is especially strong for emissions from grasslands. The $\mathrm{N}_{2} \mathrm{O}$ fluxes plotted against the $\mathrm{C} / \mathrm{N}$ ratio indicated a ratio threshold at approximately 30-35 below which high fluxes occur in the dataset (see Fig. 3c). This result provides evidence and supports the findings of Klemedtsson et al. (2005) that the $\mathrm{C} / \mathrm{N}$ ratio can be a strong predictor of $\mathrm{N}_{2} \mathrm{O}$ emissions from organic soils. Peat mineralization releases carbon as $\mathrm{CO}_{2}$, while nitrogen preferentially remains in the soil. $\mathrm{Ni}-$ trogen fertilization has a similar net effect, and thus both processes reduce the soil $\mathrm{C} / \mathrm{N}$ ratio. Therefore the $\mathrm{C} / \mathrm{N}$ ratio can be utilized as an indicator of soil processes and conditions that trigger $\mathrm{N}_{2} \mathrm{O}$ emissions. Figure $3 \mathrm{~d}$ shows that low $\mathrm{pH}$ values were related to high $\mathrm{C} / \mathrm{N}$ ratios and vice versa. The collected site data revealed a non-linear relationship between $\mathrm{pH}$ values and corresponding soil $\mathrm{C} / \mathrm{N}$ ratios. Due to unavailable data for $\mathrm{C} / \mathrm{N}$ ratios at the European level, the soil 
Table 2. Correlation matrix of $\mathrm{N}_{2} \mathrm{O}$ fluxes and potential driving parameters for the available dataset from organic soils in Europe. The parameter names are described in Table 1.

\begin{tabular}{|c|c|c|c|c|c|c|c|c|c|c|c|c|c|c|}
\hline & $\mathrm{N}_{2} \mathrm{O}$ & bd & corg & ntot & $\mathrm{ph}$ & cn & $\mathrm{pd}$ & tair & tsoil & $\mathrm{pp}$ & wt & wfps & nmin & nfert \\
\hline $\mathrm{N}_{2} \mathrm{O}$ & 1.00 & 0.17 & $-0.10^{*}$ & 0.07 & -0.05 & -0.19 & $-0.14^{*}$ & 0.06 & 0.07 & $0.11^{* *}$ & 0.32 & -0.30 & 0.10 & 0.43 \\
\hline bd & & 1.00 & -0.80 & -0.39 & 0.37 & -0.48 & -0.32 & 0.34 & -0.08 & -0.17 & 0.46 & 0.07 & -0.04 & 0.25 \\
\hline corg & & & 1.00 & 0.38 & -0.50 & 0.59 & 0.27 & -0.32 & -0.08 & 0.15 & -0.31 & -0.12 & -0.12 & $-0.13^{* *}$ \\
\hline ntot & & & & 1.00 & $0.14^{*}$ & -0.40 & 0.34 & 0.04 & 0.11 & -0.04 & -0.21 & 0.07 & $0.26^{*}$ & 0.16 \\
\hline $\mathrm{ph}$ & & & & & 1.00 & -0.64 & -0.31 & 0.06 & $0.22 *$ & -0.30 & 0.29 & -0.03 & $0.29^{* *}$ & 0.19 \\
\hline $\mathrm{cn}$ & & & & & & 1.00 & 0.02 & -0.22 & -0.18 & 0.15 & -0.20 & -0.19 & -0.36 & -0.18 \\
\hline $\mathrm{pd}$ & & & & & & & 1.00 & $0.17^{* *}$ & $0.29^{*}$ & 0.10 & -0.39 & -0.06 & -0.20 & -0.22 \\
\hline tair & & & & & & & & 1.00 & 0.77 & 0.02 & $-0.11^{*}$ & -0.01 & 0.15 & 0.16 \\
\hline tsoil & & & & & & & & & 1.00 & 0.44 & 0.15 & -0.26 & 0.27 & 0.07 \\
\hline $\mathrm{pp}$ & & & & & & & & & & 1.00 & $-0.13^{* *}$ & -0.14 & $0.24^{*}$ & 0.01 \\
\hline wt & & & & & & & & & & & 1.00 & -0.39 & 0.08 & 0.17 \\
\hline wfps & & & & & & & & & & & & 1.00 & 0.10 & -0.01 \\
\hline nmin & & & & & & & & & & & & & 1.00 & 0.10 \\
\hline nfert & & & & & & & & & & & & & & 1.00 \\
\hline
\end{tabular}

Level of significance: ${ }^{* *}$ significant at $P \leq 0.01,{ }^{*}$ significant at $P \leq 0.05$.

$\mathrm{pH}$ relationship to $\mathrm{C} / \mathrm{N}$ ratios was used as partial proxy for $\mathrm{C} / \mathrm{N}$ ratio in the regionalization. There is a general trend that managed organic soils with low $\mathrm{C} / \mathrm{N}$ ratio occur on fertile, minerotrophic peat soils with higher $\mathrm{pH}$ values while high $\mathrm{C} / \mathrm{N}$ ratios are found in nutrient-poor ombrotrophic peatlands. Nevertheless, the wide scatter of $\mathrm{pH}$ values for a given $\mathrm{C} / \mathrm{N}$ ratio indicates more complex spatial patterns, and $\mathrm{pH}$ also has an independent direct influence on $\mathrm{N}_{2} \mathrm{O}$ formation (see below). Several other studies found evidence for climate influence at particular peatland sites or regions (Dobbie et al., 1999; Sozanska et al., 2002; Lohila et al., 2010), which can be confirmed in the following land-use-stratified models.

\subsection{Model calibration and validation}

\subsubsection{Complete dataset}

We applied the fuzzy logic model approach for the entire flux dataset, which results in the best-fitted model ensemble $\left(\mathrm{NSE}_{\mathrm{cv}}=0.12\right)$ for four covariates (bulk density, groundwater table, mean winter temperate and annual precipitation). The stochastic variability within the data prevents the generic model approach from predicting the measured fluxes accurately. Thus validation results were unsatisfactory and we investigated further improvements using data partitioning with categorical parameters such as land use category, peat type and climate zone. The peat-type-stratified dataset, separated into bog, fen and shallow peat soils, results in improved model fits for each peat type. Peat type, however, cannot be regionalized due to the lack of European spatially explicit maps. In contrast to Freibauer and Kaltschmitt (2003), where $\mathrm{N}_{2} \mathrm{O}$ fluxes from temperate and sub-boreal climates on mineral soils showed different mean and maximum emissions, we found no significant differences between climate zones for $\mathrm{N}_{2} \mathrm{O}$ fluxes on organic soils. Hence the data partitioning by climate zones had no improving effect on the model performance. We achieved the best model results for land use stratification and separately developed fuzzy logic models for cropland, grassland, forest and extraction sites. Therefore each land use model has a different number and range of observations, as well as different covariates. Table 3 gives an overview for the land-use-specific $\mathrm{N}_{2} \mathrm{O}$ flux data and corresponding model performances.

\subsubsection{Cropland}

The best-fitted cropland model has a model efficiency of $\mathrm{NSE}=0.63$ and was calibrated for three parameters - topsoil $\mathrm{pH}$, the mean groundwater table and the annual precipitation amount. These model covariates were validated for $40 \mathrm{ob}-$ servations from 20 sites on which all three model parameter were available in our dataset. The range of $\mathrm{N}_{2} \mathrm{O}$ fluxes from the cropland sub-dataset $(-0.02,3.70)$ in $\mathrm{g} \mathrm{N}_{2} \mathrm{O}-\mathrm{N} \mathrm{m}^{-2} \mathrm{a}^{-1}$ was comparable to the range of the complete cropland dataset $(-0.02,6.10)$. Only a few extremely high fluxes were excluded, and so the mean values are equivalent. Using this sub-dataset, we were able to achieve the best model fit of $\mathrm{NSE}_{\mathrm{cv}}=0.41$ in terms of an independent cross validation (compare Fig. 4).

As has been mentioned in Sect. 3.1, the topsoil $\mathrm{pH}$ of croplands was not only correlated to $\mathrm{N}_{2} \mathrm{O}$ emissions $(r=-0.53$, $p<0.001)$ but also significantly to the $\mathrm{C} / \mathrm{N}$ ratio $(r=-0.68$, $p<0.001$ ). Mørkved et al. (2007) suggested the soil $\mathrm{pH}$ to be a strong controlling factor for $\mathrm{N}_{2} \mathrm{O}$ fluxes because it affects the $\mathrm{N}_{2} \mathrm{O}$ production processes of both denitrification and nitrification. Additionally they stated that low-pH soils have higher $\mathrm{N}_{2} \mathrm{O} / \mathrm{N}_{2}$ production ratios and thus higher potential $\mathrm{N}_{2} \mathrm{O}$ emissions. The described effect is also observable for fluxes from croplands on organic soils. Weslien et al. (2009) also found a strong negative correlation of soil $\mathrm{pH}$ and $\mathrm{N}_{2} \mathrm{O}$ emissions in their data. They argued that the dinitrogen 
Table 3. List of calibrated and validated $\mathrm{N}_{2} \mathrm{O}$ fuzzy logic models with covariates that are described in Table 1 (Parameters), number of flux measurements $\left(\mathrm{N}_{\text {flux }}\right)$ and model performances of calibration $\left(\mathrm{NSE}_{\mathrm{cali}}\right)$ and cross validation $\left(\mathrm{NSE}_{\mathrm{cv}}\right)$ for different land use categories, respectively.

\begin{tabular}{lllll}
\hline Land use & Parameters & $N_{\text {flux }}$ & NSE $_{\text {cali }}$ & NSE $_{\mathrm{cv}}$ \\
\hline Crop & wt, ph, pp & 40 & 0.63 & 0.41 \\
Grass & nfert, tair winter, & 96 & 0.68 & 0.58 \\
& pp autumn & & & \\
Forest & wt, ph, tair & 60 & 0.66 & 0.25 \\
Extraction & bd, pp, tair winter & 21 & 0.89 & 0.28 \\
Natural & - & 132 & - & - \\
\hline
\end{tabular}

oxide reductase is inhibited by acidic $\mathrm{pH}$ and can thus enhance $\mathrm{N}_{2} \mathrm{O}$ emissions (Firestone and Davidson, 1989; Skiba and Smith, 1993). This result is supported by the findings of Liu et al. (2010), who found a strong negative correlation between the $\mathrm{N}_{2} \mathrm{O} / \mathrm{N}_{2}$ product ratio of denitrification and soil $\mathrm{pH}$.

The second important parameter in the model, the groundwater table, is well known as a proxy for oxygen availability in topsoil and can therefore significantly control the $\mathrm{N}_{2} \mathrm{O}$ production processes (Regina et al., 1996; van Beek et al., 2010). We found a correlation between $\mathrm{N}_{2} \mathrm{O}$ and groundwater table in the cropland dataset which confirmed this significance $(r=0.31, p<0.05)$. The model indicates that deep drainage induces higher fluxes of $\mathrm{N}_{2} \mathrm{O}$. In contrast to Fig. 3a, which includes all land use categories, the model structure for the relationship of groundwater table and $\mathrm{N}_{2} \mathrm{O}$ fluxes for croplands only was linear and not in the form of a humpshaped, non-linear curve. The sub-dataset for croplands indicated a linear increase in $\mathrm{N}_{2} \mathrm{O}$ fluxes with deep drainage. Furthermore, precipitation emerged as the third model component. Precipitation increases the WFPS in topsoil and can trigger $\mathrm{N}_{2} \mathrm{O}$ flux peaks immediately after the rain events (Dobbie et al., 1999; Dobbie and Smith, 2003). High annual precipitation amounts can increase the probability of such $\mathrm{N}_{2} \mathrm{O}$ peak flux events in drained agriculturally used organic soils.

The expected role of $\mathrm{N}$ fertilizer, i.e. as a $\mathrm{N}_{2} \mathrm{O}$ emission amplifier on croplands (Velthof and Oenema, 1995; Skiba et al., 1998), could not be confirmed in our modelling approach. Both the statistical analysis, shown in Fig. 3b, and the fuzzy modelling approach found no significant relationship of $\mathrm{N}_{2} \mathrm{O}$ fluxes and $\mathrm{N}$ fertilization. Organic soils under croplands had $\mathrm{C} / \mathrm{N}$ ratios below 30 and are likely strong sources of nitrogen from peat mineralization. Assuming a soil carbon loss from mineralized peat of $7.9 \mathrm{tCha}^{-1} \mathrm{a}^{-1}$, as suggested by the IPCC (IPCC, 2013, Table 2.1), it would result in a mean $\mathrm{N}$ mineralization of approximately $424.7 \mathrm{~kg} \mathrm{ha}^{-1} \mathrm{a}^{-1}$ for cropland sites in our database with average $\mathrm{C} / \mathrm{N}$ ratios of $18.6 \pm 5.8$. This exceeds the maximum amount of $\mathrm{N}$ fertilizer $\left(288.8 \mathrm{~kg} \mathrm{ha}^{-1}\right)$ that has been applied to cropland sites. The

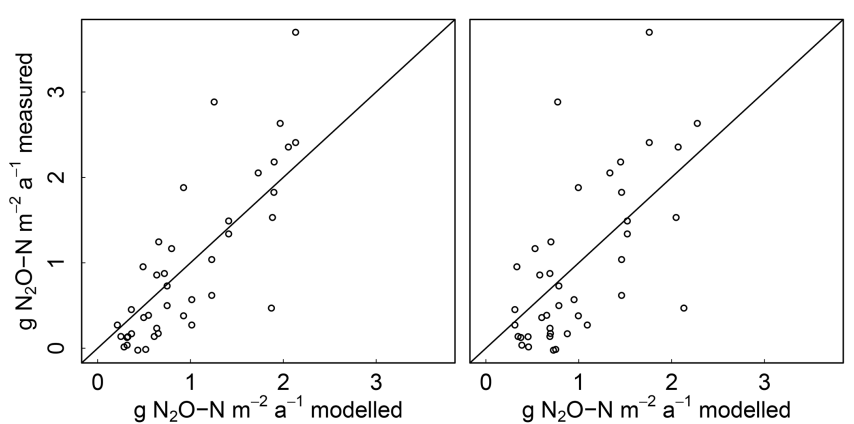

Figure 4. Fuzzy model performance for calibration and cross validation of $\mathrm{N}_{2} \mathrm{O}$ fluxes from cropland on organic soils. The modelled fluxes ( $x$ axis) represent the mean flux rates from a model ensemble of 50 individually bootstrapped models. The cross validation was performed by excluding one site per iteration.
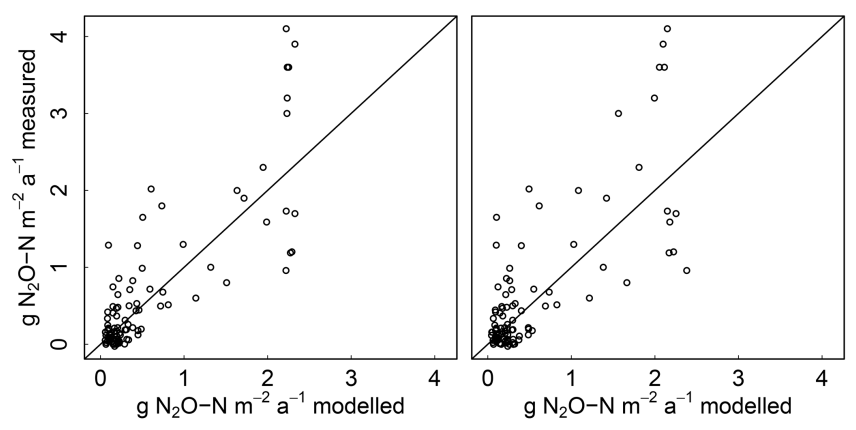

Figure 5. Fuzzy model results for calibration and cross validation for $\mathrm{N}_{2} \mathrm{O}$ fluxes from grassland on organic soils. The modelled fluxes ( $x$ axis) represent the mean flux rates from a model ensemble of 50 individually bootstrapped models. The cross validation was performed by excluding one site per iteration.

estimated mean $\mathrm{N}$ mineralization suggests that, independent of fertilizer application, sufficient substrate for $\mathrm{N}_{2} \mathrm{O}$ production is available and that the $\mathrm{N}_{2} \mathrm{O}$ production is not limited by external $\mathrm{N}$ input. All high fluxes from croplands were measured on deeply drained sites, which is also reflected in the regionalization by using the groundwater distribution with a mean water table of $0.58 \mathrm{~m}$ below surface. In summary, sensitivity analysis shows that the cropland model predicts the highest emissions on sites with a combination of deep drainage, a soil $\mathrm{pH}$ around 4.0 and a high amount of annual precipitation, whereas the lowest emissions occur for soils with higher $\mathrm{pH}$ values and water table near the surface, regardless of rainfall.

\subsubsection{Grassland}

Grasslands are the best-observed land use category, represented by 217 annual flux measurements. The automatic calibration results in a fuzzy model with three parameters, which can explain about $68 \%$ of the variability in the flux data $(\mathrm{NSE}=0.68)$. The parameters are nitrogen fertilizer amount, 

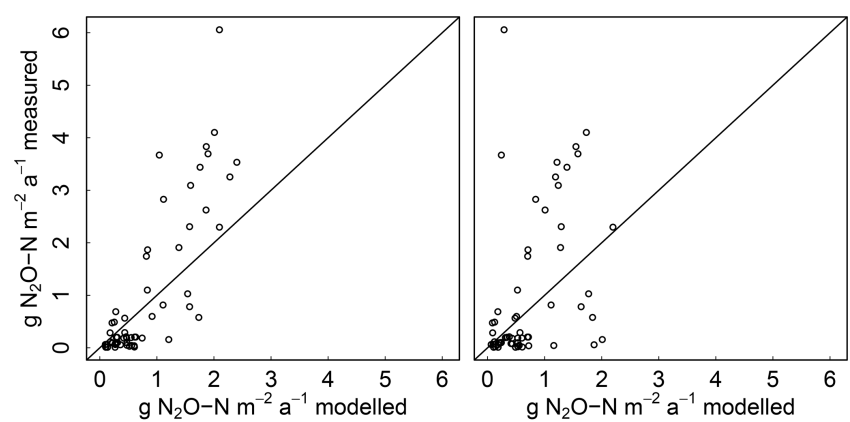

Figure 6. Fuzzy model results for calibration and cross validation for $\mathrm{N}_{2} \mathrm{O}$ fluxes from forest sites on organic soils. The modelled fluxes ( $x$ axis) represent the mean flux rates from a model ensemble of 50 individually bootstrapped models. The cross validation was performed by excluding one site per iteration.

mean winter temperature and precipitation in autumn. The required parameter combination is available for 96 observations from 44 sites that cover the $\mathrm{N}_{2} \mathrm{O}$ flux range of $(-0.03$, 4.10) with a higher mean $(\bar{x}=0.67)$ than the complete grassland dataset $\left(\bar{x}=0.58 \mathrm{~g} \mathrm{~N}_{2} \mathrm{O}-\mathrm{N} \mathrm{m}^{-2} \mathrm{a}^{-1}\right)$. The cross validation could reproduce nearly $60 \%$ of the variability in the data $\left(\mathrm{NSE}_{\mathrm{cv}}=0.58\right)($ Fig. 5). In agreement with the statistical analysis (Fig. 3b), we also found the significant relationship of $\mathrm{N}_{2} \mathrm{O}$ fluxes and $\mathrm{N}$ fertilization for the grasslands fuzzy model approach. The amount of $\mathrm{N}$ fertilization was directly correlated $(r=0.54, p<0.05)$ to the fluxes from grassland sites, whereas no relationship was found for croplands. In fact, the N-fertilization amount was the most important model parameter. The importance of $\mathrm{N}$ fertilization has been recognized in several other studies on organic soils (Velthof and Oenema, 1995; Skiba et al., 1998). The different responses for grassland and cropland have also been observed and modelled for $\mathrm{N}_{2} \mathrm{O}$ fluxes from mineral soils (Dechow and Freibauer, 2011). Furthermore different sensitivities to $\mathrm{N}$ fertilization on temperate and sub-boreal agricultural mineral soils are discussed in Freibauer and Kaltschmitt (2003) and Roelandt et al. (2005).

In addition to the management influence, the mean winter air temperature is also correlated to $\mathrm{N}_{2} \mathrm{O}$ fluxes $(r=0.40$, $p<0.05$ ) and was identified as a second important model parameter. The emissions increased with rising winter air temperatures up to maximum values approximately around $0{ }^{\circ} \mathrm{C}$. This relation of $\mathrm{N}_{2} \mathrm{O}$ fluxes to mean temperatures in winter months (December, January and February) can be a proxy for the amount of released emissions due to freeze-thaw cycles as described in Freibauer and Kaltschmitt (2003) and Jungkunst et al. (2006). Although the interaction of parameters, e.g. air temperature, WFPS and snow cover, that can induce freeze-thaw cycles is complex and highly variable, the model successfully worked with winter temperature as a simple input parameter. This is especially useful with regard to model upscaling attempts, because the temperature,

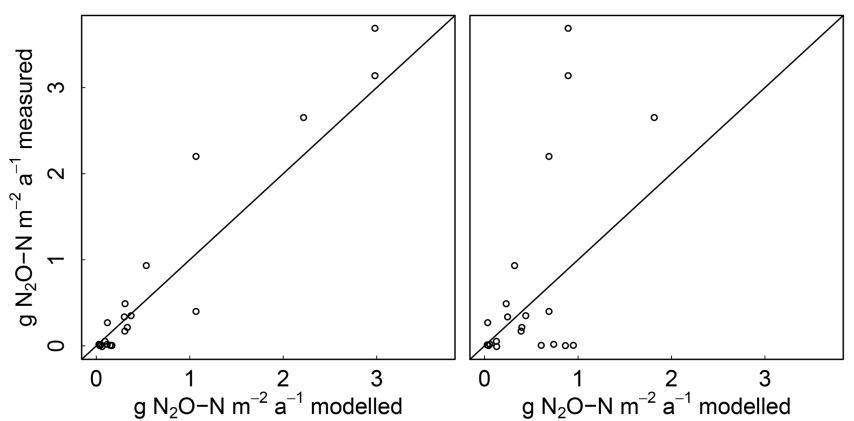

Figure 7. Fuzzy model results for calibration and cross validation for $\mathrm{N}_{2} \mathrm{O}$ fluxes from peat extraction sites on organic soils. The modelled fluxes ( $x$ axis) represent the mean flux rates from a model ensemble of 50 individually bootstrapped models. The cross validation was performed by excluding one site per iteration.

as well as the winter temperature only, is easily available at the European level.

Autumn precipitation emerged as the third model component. We observed a positive correlation $(r=0.50$, $p<0.05$ ) between the rainfall amount in autumn months (September, October and November) and the $\mathrm{N}_{2} \mathrm{O}$ fluxes on grassland sites. As stated before, precipitation can increase the WFPS in topsoil and trigger $\mathrm{N}_{2} \mathrm{O}$ fluxes (Dobbie et al., 1999). This strong statistical relation between autumn precipitation and $\mathrm{N}_{2} \mathrm{O}$ has not been described before for organic grasslands, but agrees with evidence in mineral croplands Dechow and Freibauer (2011). High precipitation in autumn leaves wet soils in winter, which is a precondition for freeze-thaw peaks of $\mathrm{N}_{2} \mathrm{O}$ emissions. In summary, grasslands $\mathrm{N}_{2} \mathrm{O}$ fluxes are sensitive to $\mathrm{N}$ fertilization and seasonal precipitation and temperatures. Highest emissions are expected for intensively managed grasslands with high $\mathrm{N}$ input, which are controlled by winter temperature and rainfall events in autumn.

\subsubsection{Forest}

The measured forest $\mathrm{N}_{2} \mathrm{O}$ fluxes in the dataset $(n=170)$ are dominantly located in boreal $(61 \%)$ and sub-boreal regions $(22 \%)$, whereas temperate forest sites make up only a small percentage $(17 \%)$. These climatic regions have different mean $\mathrm{N}_{2} \mathrm{O}$ emissions $0.51,0.33$ and 0.26 in $\mathrm{g} \mathrm{N}_{2} \mathrm{O}$ $\mathrm{N} \mathrm{m}^{-2} \mathrm{a}^{-1}$ for temperate, sub-boreal and boreal climates, respectively. However the range within the climatic regions are comparable and no significant difference between mean $\mathrm{N}_{2} \mathrm{O}$ fluxes is recognizable. The best-fitted forest model consisted of three parameters: mean groundwater table, topsoil $\mathrm{pH}$ and the annual mean air temperature with a model efficiency of $\mathrm{NSE}=0.66$. The corresponding sub-dataset consisted of 60 observations from 38 sites that cover the $\mathrm{N}_{2} \mathrm{O}$ flux range of $(0.01,6.06)$ in $\mathrm{g} \mathrm{N}_{2} \mathrm{O}-\mathrm{N} \mathrm{m}^{-2} \mathrm{a}^{-1}$, which is almost identical to the complete forest dataset. The cross validation left significant variability unexplained $\left(\mathrm{NSE}_{\mathrm{cv}}=0.25\right)$. Clearly, the 


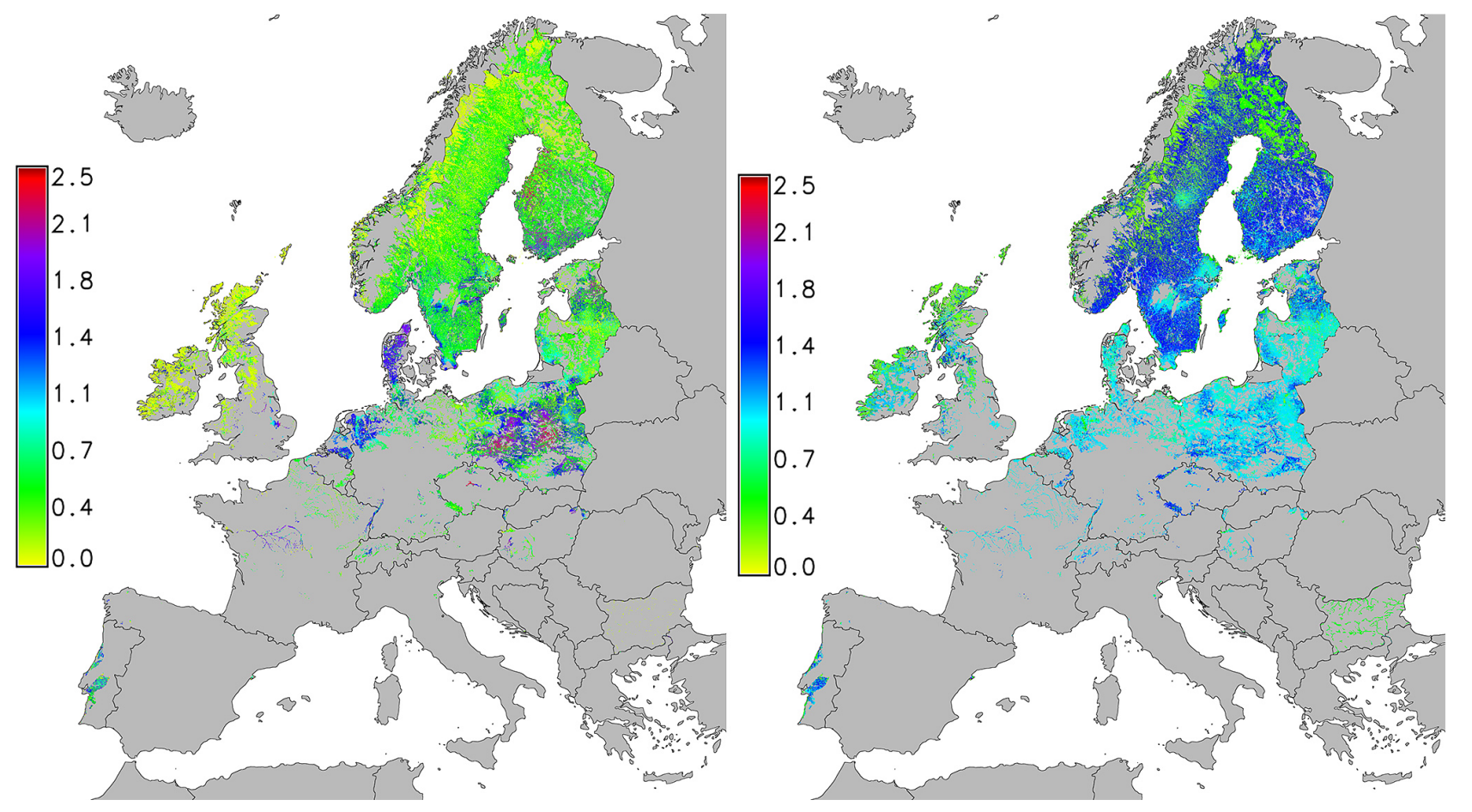

Figure 8. European $\mathrm{N}_{2} \mathrm{O}$ fluxes for $1 \mathrm{~km} \times 1 \mathrm{~km}$ raster grid cells calculated with the fuzzy logic model approach (left) and the corresponding pixel-wise model uncertainty as standard deviations (right) for organic soils in $\mathrm{g} \mathrm{N}_{2} \mathrm{O}-\mathrm{N} \mathrm{m}^{-2} \mathrm{a}^{-1}$. The land use classification is based on CORINE land cover.

validation dataset is too small to robustly describe general relationships.

Topsoil $\mathrm{pH}$ turned out as most important driver with higher $\mathrm{N}_{2} \mathrm{O}$ emissions for $\mathrm{pH}$ values lower than 5.5. In forests we also observed $\mathrm{C} / \mathrm{N}$ ratios below 30 under acid conditions. Therefore the stated relationship between $\mathrm{pH}$ and $\mathrm{C} / \mathrm{N}$ exhibits too much variation to get utilized. Nevertheless, the soil $\mathrm{pH}$ can be selected directly as driver for $\mathrm{N}_{2} \mathrm{O}$ emissions because it explains a major part of the variability. The response of $\mathrm{N}_{2} \mathrm{O}$ in organic soils under forests thus resembles the response under cropland.

The mean annual groundwater table was modelled as a hump-shaped function, similar to Fig. 3a, and predicted the highest $\mathrm{N}_{2} \mathrm{O}$ fluxes in a drainage range from 0.4 to $0.8 \mathrm{~m}$ below ground. Martikainen et al. (1993) and Regina et al. (1996) stated that lowering the water table in boreal peatlands increases the $\mathrm{N}_{2} \mathrm{O}$ fluxes from soils, especially more in minerotrophic than in ombrotrophic sites. The presented forest model can reproduce this effect, due to the combination of groundwater table and $\mathrm{pH}$ value, which can be utilized as a proxy for nutrient supply.

Mean annual air temperature was identified as a third model parameter with increasing $\mathrm{N}_{2} \mathrm{O}$ emissions in warmer regions. In general the model predicts lower $\mathrm{N}_{2} \mathrm{O}$ fluxes from forest sites in comparison to crop- and grassland sites and only a few hotspot emissions appeared under drained, nutrient-rich and warm conditions.

\subsubsection{Peat extraction}

$\mathrm{N}_{2} \mathrm{O}$ flux data were only represented by 35 observations from 20 different peat extraction sites. The $\mathrm{N}_{2} \mathrm{O}$ fluxes from extraction sites ranged from -0.01 to 3.69 with a mean of $0.47 \mathrm{~g} \mathrm{~N}_{2} \mathrm{O}-\mathrm{N} \mathrm{m}^{-2} \mathrm{a}^{-1}$. The fuzzy logic model calibration achieved the best performance (NSE $=0.89$ ) with three parameters: the topsoil bulk density, the annual precipitation and the winter temperature. The required parameters were available for 21 observations from 12 sites with a similar mean and range for $\mathrm{N}_{2} \mathrm{O}$ fluxes in comparison to the complete peat extraction dataset. The best-fitted model achieved a model performance of $\mathrm{NSE}_{\mathrm{cv}}=0.28$. Comparable to the forest model validation, the dataset is also too small to robustly describe general relationships for extraction sites. The bulk density of topsoils was strongly correlated $(r=0.9$, $p<0.05$ ) to $\mathrm{N}_{2} \mathrm{O}$ fluxes from extraction sites, with highest $\mathrm{N}_{2} \mathrm{O}$ emissions from compacted sites. The range of bulk densities from extraction sites covered loosely packed natural peat densities as well as densities of high compaction, which indicate strong peat degradation. This wide range of bulk densities could be related to variations in management intensity on extraction sites. The $\mathrm{N}_{2} \mathrm{O}$ response to winter temperature and annual precipitation agrees with patterns found for croplands and grasslands. The limited data availability for peat extraction sites can provoke a systematic bias and thus restrict the model upscaling accuracy. On the other hand, 
peat extraction sites comprise only a small percentage of land area and have relatively low flux rates in comparison to other land use categories, e.g. cropland, grassland or forest. Therefore the impact on the European $\mathrm{N}_{2} \mathrm{O}$ emission budget is very small.

\subsubsection{Natural peatland}

Natural, pristine peatlands are characterized by wet conditions and peat growth. In these ecosystems the groundwater table is the limiting factor for $\mathrm{N}_{2} \mathrm{O}$ emissions, because waterlogged soils generally have a low amount of oxygen available, which decreases the $\mathrm{N}_{2} \mathrm{O}$ production rate (Firestone and Davidson, 1989). We have 132 observations from 64 different sites with a mean flux of $0.07 \mathrm{~g} \mathrm{~N}_{2} \mathrm{O}-\mathrm{N} \mathrm{m}^{-2} \mathrm{a}^{-1}$ in a range of -0.43 to 0.45 in our database. We also included rewetted peatlands that exhibit the majority of the sparsely occurring higher fluxes. Some of these restored sites are still in a transitional phase after recent restoration, and shallow drainage persists in some rewetted sites. These human influences could explain outlier $\mathrm{N}_{2} \mathrm{O}$ emissions. We were not able to find a significant statistical relationship between gathered driving parameters and $\mathrm{N}_{2} \mathrm{O}$ fluxes. The automatic calibration of the fuzzy model also could not identify a parameter combination that has a greater explanatory power than the mean flux. Therefore we used the mean value of $\mathrm{N}_{2} \mathrm{O}$ fluxes for calculating emission budgets in further model applications. In general the $\mathrm{N}_{2} \mathrm{O}$ fluxes from natural organic soils are very low, and even consumption can occur in wet, nitrogenpoor soils (Chapuis-Lardy et al., 2007). Hence the contribution to the European $\mathrm{N}_{2} \mathrm{O}$ emission budget is comparatively small. The IPCC wetland supplement even reported zero fluxes of $\mathrm{N}_{2} \mathrm{O}$ for natural peatlands (IPCC, 2013). Nonetheless, fluxes from natural peatlands represent the background $\mathrm{N}_{2} \mathrm{O}$ emissions that are expected from peatland areas without any anthropogenic management and therefore could provide useful information for estimating human influence.

\subsection{Uncertainties}

The quality of the spatial datasets for the regionalization adds an unknown bias. The pixel information in the soil map contains aggregated data, which may not be representative of the peat soils. Bulk density data in the European soil map were in the range of mineral soils and thus considered implausible and inadequate for regionalization. The $\mathrm{pH}$ range of the European soil map agreed with the $\mathrm{pH}$ range in the observational dataset, but it remains unclear whether agricultural practices such as liming have been considered and whether the $\mathrm{pH}$ values given in the soil map are representative of the land uses on the peat soils.

A sensitivity analysis of the fuzzy models showed that driving parameter uncertainty dominated over model uncertainty except for the forest model. Our approach to estimate the driving parameters mean water table and bulk density, which are unavailable at the European level, is not necessarily spatially representative of Europe. The water table constitutes the major source of uncertainty and likely bias in the European $\mathrm{N}_{2} \mathrm{O}$ inventory. Improvements in the spatial representation of water table annual mean values as those by Bechtold et al. (2014) and seasonal fluctuations would also strongly enhance inventory accuracy.

\subsection{Hotspots of $\mathrm{N}_{2} \mathrm{O}$ emissions}

Figure 8 shows the European $\mathrm{N}_{2} \mathrm{O}$ emission map of organic soils with pixel-wise uncertainties derived by regionalization of the models presented in Sect. 3.2. For all land use types, computed distributions were positively skewed.

\subsubsection{Regions}

$\mathrm{N}_{2} \mathrm{O}$ emission hotspots from croplands $\left(1.8-2.43 \mathrm{~g} \mathrm{~N}_{2} \mathrm{O}-\right.$ $\mathrm{N} \mathrm{m}^{-2} \mathrm{a}^{-1}$ ) were located in northern Denmark, Poland, Estonia and southern Finland. All hotspot regions were related to low soil $\mathrm{pH}<4.7$, which seems to be the main driving parameter for cropland $\mathrm{N}_{2} \mathrm{O}$ emissions at continental scale. $\mathrm{N}_{2} \mathrm{O}$ emissions from croplands are generally highest and also have the highest $\mathrm{N}_{2} \mathrm{O}$ hotspots of all land use categories. Approximately $35 \%$ of $\mathrm{N}_{2} \mathrm{O}$ emissions from cropland exceeded the maximum grassland and $87 \%$ exceeded the maximum forest emissions.

The grassland emission hotspots $\left(0.54-1.64 \mathrm{~g} \mathrm{~N}_{2} \mathrm{O}-\mathrm{N} \mathrm{m}^{-2}\right.$ $\mathrm{a}^{-1}$ ) were predominantly located in the Netherlands, Germany, Ireland and in the Baltic states. These hotspots were linked to high $\mathrm{N}$-fertilization rates larger than $250 \mathrm{~kg} \mathrm{ha}^{-1}$, warmer winter temperatures above $0^{\circ} \mathrm{C}$ and more than 160 $\mathrm{mm}$ rainfall in autumn.

Forests had a relatively small span in $\mathrm{N}_{2} \mathrm{O}$ emissions and low peak emissions (0.59-0.8 $\left.\mathrm{g} \mathrm{N}_{2} \mathrm{O}-\mathrm{N} \mathrm{m}^{-2} \mathrm{a}^{-1}\right)$, which only reached one-third of the cropland maximum and half of the grassland maximum, respectively. The highest flux rates were scattered all over European forest sites on peatlands and were related to $\mathrm{pH}$ values lower than 5 similar to the pattern of cropland $\mathrm{N}_{2} \mathrm{O}$ hotspots. In addition, the forest $\mathrm{N}_{2} \mathrm{O}$ emissions increased especially for annual mean temperatures above $6^{\circ} \mathrm{C}$, which coincides with a higher fraction of minerotrophic peat soils.

The hotspot emissions from extraction sites $\left(0.78-0.87 \mathrm{~g} \mathrm{~N}_{2} \mathrm{O}-\mathrm{N} \mathrm{m}^{-2} \mathrm{a}^{-1}\right)$ were in the same range as forest hotspots and were evenly distributed across Finland and the Baltic states. They were driven by annual precipitation above $500 \mathrm{~mm}$ and winter temperatures around $0{ }^{\circ} \mathrm{C}$.

Natural sites were represented with the mean $\mathrm{N}_{2} \mathrm{O}$ flux of $0.07 \mathrm{~g} \mathrm{~N}_{2} \mathrm{O}-\mathrm{N} \mathrm{m}^{-2} \mathrm{a}^{-1}$ from natural sites in the database and therefore set as constant across Europe. 
Table 4. $\mathrm{N}_{2} \mathrm{O}$ emission budget for European peatlands from different approaches: fuzzy logic model (Fuzzy), average emission factors of flux data from this study (Average) and IPCC emission factor approach (IPCC) are shown as mean and $95 \%$ confidence interval of the budgets in $\mathrm{Gg} \mathrm{N}_{2} \mathrm{O}-\mathrm{N} \mathrm{a}^{-1}$. The land use categories are based on CLC 2006 (top) and HILDA 2010 (bottom).

\begin{tabular}{l|rrr|rrr|rrr}
\hline & \multicolumn{3}{|c|}{ Fuzzy } & \multicolumn{3}{c|}{ Average } & \multicolumn{3}{c}{ IPCC } \\
\hline Land use & Mean & \multicolumn{2}{c|}{$95 \%$ Conf. int. } & Mean & $95 \%$ Conf. int. & Mean & 95\% Conf. int. \\
\hline Crop & 71.734 & 63.903 & 79.565 & 42.443 & 33.113 & 51.730 & 56.417 & 35.586 & 78.116 \\
Grass & 7.848 & 2.856 & 12.841 & 15.687 & 12.036 & 19.365 & 22.780 & 13.080 & 31.180 \\
Forest & 64.005 & 37.980 & 90.031 & 42.157 & 26.730 & 57.583 & 8.196 & 0.524 & 15.612 \\
Extraction & 0.099 & -0.045 & 0.240 & 0.134 & 0.050 & 0.218 & 0.009 & -0.001 & 0.018 \\
Natural & 5.795 & 2.078 & 9.513 & 5.795 & 2.041 & 9.469 & 0.000 & 0.000 & 0.000 \\
\hline Sum & 149.482 & 93.718 & 205.246 & 106.216 & 68.701 & 143.732 & 87.402 & 53.980 & 120.824 \\
\hline Crop & 40.446 & 36.282 & 44.609 & 22.512 & 17.563 & 27.438 & 29.924 & 18.875 & 41.433 \\
Grass & 29.103 & 12.530 & 45.675 & 53.768 & 41.253 & 66.376 & 82.143 & 43.971 & 116.158 \\
Forest & 63.115 & 36.031 & 90.199 & 45.814 & 29.050 & 62.579 & 9.070 & 0.524 & 17.334 \\
\hline Sum & 132.663 & 76.899 & 188.428 & 122.095 & 84.579 & 159.610 & 121.137 & 72.515 & 169.758 \\
\hline
\end{tabular}

Table 5. Overview of land use areas on organic soils in Europe and corresponding implied emission factors (iEF) for the Fuzzy logic model (Fuzzy), the average emission factors of flux data from this study (Average) and IPCC emission factor approach (IPCC). The land areas are shown in $\mathrm{km}^{2}$ for CLC 2006 (top) and HILDA 2010 (bottom), respectively. The emission factors are derived from the mean $\mathrm{N}_{2} \mathrm{O}$ flux budget divided by particular land use class area and are displayed in $\mathrm{g} \mathrm{N}_{2} \mathrm{O}-\mathrm{N} \mathrm{m}^{-2} \mathrm{a}^{-1}$.

\begin{tabular}{lrrrr}
\hline Land use & Area & $\begin{array}{r}\text { Fuzzy } \\
\text { iEF }\end{array}$ & $\begin{array}{r}\text { Average } \\
\text { iEF }\end{array}$ & $\begin{array}{r}\text { IPCC } \\
\text { iEF }\end{array}$ \\
\hline Crop & 43397.84 & 1.653 & 0.978 & 1.300 \\
Grass & $27,046.10$ & 0.290 & 0.580 & 0.842 \\
Forest & 132986.80 & 0.421 & 0.317 & 0.062 \\
Extraction & 283.35 & 0.349 & 0.473 & 0.032 \\
Natural & 81626.15 & 0.071 & 0.071 & 0 \\
\hline Crop & 23018.50 & 1.757 & 0.978 & 1.300 \\
Grass & 92703.48 & 0.314 & 0.580 & 0.842 \\
Forest & 144525.03 & 0.410 & 0.317 & 0.062 \\
\hline
\end{tabular}

\subsubsection{Evidence}

The hotspot locations of $\mathrm{N}_{2} \mathrm{O}$ fluxes from cropland sites can be confirmed by measurements in the database from Denmark (Petersen et al., 2012), southern Finland and Germany. Observed $\mathrm{N}_{2} \mathrm{O}$ fluxes of up to $6.11 \mathrm{~g} \mathrm{~N}_{2} \mathrm{O}-\mathrm{N} \mathrm{m}^{-2} \mathrm{a}^{-1}$ from soils with low $\mathrm{pH}$ between 4.0 and 5.5 support the model results. Unfortunately, the modelled hotspot regions in Poland cannot be validated with observations.

Grassland emission hotspots in the Netherlands and Germany have been observed in several studies (Velthof and Oenema, 1995; van Beek et al., 2010; Wild et al., 1998) and are well represented in our dataset. In general the grassland model (Sect. 3.2.3) and the spatial patterns show a strong signal from anthropogenically induced emissions which is slightly modified by seasonal climate conditions. The contrasts between croplands and grasslands have not been described before on organic soils but agree with $\mathrm{N}_{2} \mathrm{O}$ responses described for mineral soils at national and European level (Jungkunst et al., 2006; Dechow and Freibauer, 2011).

In forests, the highest forest $\mathrm{N}_{2} \mathrm{O}$ flux measurements were found in boreal peatlands in Finland and Sweden (Klemedtsson et al., 1997; Weslien et al., 2009), as well as in a forest in Slovenia (Danevčič et al., 2010), which exceeds the highest fluxes by the forest model. Remarkably, all of these $\mathrm{N}_{2} \mathrm{O}$ hotspot fluxes are also related to a low soil $\mathrm{pH}$ of under 4.7 and $\mathrm{C} / \mathrm{N}$ ratios below 20 , which is consistent with the relation of $\mathrm{N}_{2} \mathrm{O}$ fluxes, $\mathrm{pH}$ values and $\mathrm{C} / \mathrm{N}$ ratios for the whole dataset in Fig. 3d.

In extraction sites, $\mathrm{N}_{2} \mathrm{O}$ emission hotspots occurred in the Baltic region. These were of the same magnitude as the highest flux data from extraction sites observed in Estonia (Salm et al., 2011).

\subsubsection{Variability}

The cropland model hotspot uncertainties ranged from 0.90 up to 1.01 and were comparable to the grassland uncertainties (0.92-1.07 $\left.\mathrm{g} \mathrm{N}_{2} \mathrm{O}-\mathrm{N} \mathrm{m}^{-2} \mathrm{a}^{-1}\right)$ for hotspot emissions. In both land use types, modelled $\mathrm{N}_{2} \mathrm{O}$ flux rates clearly exceed the uncertainty range. The $\mathrm{N}_{2} \mathrm{O}$ emission pattern from croplands and grasslands can thus be considered robust. This finding gives important information regarding where to focus $\mathrm{N}_{2} \mathrm{O}$ mitigation since croplands and grasslands represent the main source of $\mathrm{N}_{2} \mathrm{O}$ emissions per area and for the total European emission inventory (see Sect. 3.5)

In contrast, the highest forest and peat extraction fluxes had higher uncertainties (1.31-1.51) and (0.96-1.38 $\mathrm{g} \mathrm{N}_{2} \mathrm{O}$ $\mathrm{N} \mathrm{m}^{-2} \mathrm{a}^{-1}$ ) than modelled $\mathrm{N}_{2} \mathrm{O}$ flux rates. The high 
Table 6. List of sites with number of flux measurements and references that are included in the presented meta-study.

\begin{tabular}{|c|c|c|c|c|c|}
\hline Name & $\begin{array}{l}\text { Number } \\
\text { of sites }\end{array}$ & $\begin{array}{l}\text { Number } \\
\text { of fluxes }\end{array}$ & Start date & End date & Reference \\
\hline Aardlapalu & 1 & 2 & 2009-01-01 & $2010-12-31$ & Salm et al. (2011) \\
\hline Ahlenmoor & 6 & 17 & 2008-01-01 & $2011-12-31$ & $\begin{array}{l}\text { Beetz et al. (2013), } \\
+ \text { unpublished data }\end{array}$ \\
\hline Alkkia & 1 & 1 & 2003-05-01 & 2004-04-30 & Mäkiranta et al. (2007) \\
\hline Apukka & 1 & 6 & 2001-01-01 & $2002-12-31$ & Regina et al. (2004) \\
\hline Asa & 4 & 6 & 2000-01-01 & $2001-12-31$ & Arnold et al. (2005) \\
\hline Benediktbeuern & 6 & 6 & 2005-01-01 & $2005-12-31$ & unpublished data \\
\hline Bodin & 5 & 8 & 2003-01-01 & $2003-12-31$ & Kløve et al. (2010) \\
\hline Bodo & 3 & 8 & 2003-01-01 & 2004-12-31 & Grønlund et al. (2006) \\
\hline Central Finland & 12 & 35 & 1991-01-01 & $1992-12-31$ & Regina et al. (1996) \\
\hline Donaumoos & 7 & 7 & 1994-01-01 & $1999-12-31$ & Wild et al. (1998) \\
\hline Donauried & 5 & 5 & 2004-01-01 & $2004-12-31$ & unpublished data \\
\hline Dümmer & 6 & 16 & 2008-01-01 & 2011-12-31 & unpublished data \\
\hline Dummerstorf & 5 & 6 & 2010-01-01 & $2011-12-31$ & unpublished data \\
\hline Falköping & 9 & 9 & 1995-01-01 & $1997-12-31$ & $\begin{array}{l}\text { Weslien et al. (2009), } \\
\text { Klemedtsson et al. (2009) }\end{array}$ \\
\hline Falla & 1 & 1 & 2008-01-01 & 2009-12-31 & Strömgren et al. (2014) \\
\hline Finland & 50 & 69 & 2007-01-01 & $2008-12-31$ & Ojanen et al. (2010) \\
\hline Flanders Moss & 4 & 4 & 2009-01-01 & $2009-12-31$ & Yamulki et al. (2013) \\
\hline Flugebo & 1 & 1 & 2008-01-01 & $2008-12-31$ & Strömgren et al. (2014) \\
\hline Freising & 29 & 50 & 2007-01-01 & $2012-12-31$ & $\begin{array}{l}\text { Eickenscheidt et al. (2013), } \\
\text { Eickenscheidt et al. (2014), } \\
\text { + unpublished data }\end{array}$ \\
\hline Fyodorovskoye & 1 & 3 & 2009-01-01 & 2011-12-31 & unpublished data \\
\hline Graben-Neudorf & 5 & 10 & 2010-01-01 & 2011-12-31 & Peichl-Brak (2013) \\
\hline Grosses Moor & 6 & 12 & 2011-01-01 & $2012-12-31$ & $\begin{array}{l}\text { Leiber-Sauheitl et al. (2014), } \\
+ \text { unpublished data }\end{array}$ \\
\hline Gullhult & 1 & 1 & 2008-01-01 & $2008-12-31$ & Strömgren et al. (2014) \\
\hline Gumnitz & 2 & 10 & 1995-01-01 & $1999-12-31$ & Augustin et al. (1998) \\
\hline Halolanmaeki & 5 & 6 & 1996-01-01 & $1997-12-31$ & Maljanen et al. (2003) \\
\hline Harz & 2 & 2 & 2002-01-01 & $2002-12-31$ & Tauchnitz et al. (2008) \\
\hline Heinrichswalde & 6 & 18 & 1995-01-01 & $1999-12-31$ & ZALF unpublished data \\
\hline Hiiesoo & 1 & 4 & 2009-01-01 & $2009-12-31$ & Salm et al. (2011) \\
\hline Ilomantsi & 2 & 5 & 1991-01-01 & $1992-12-31$ & Nykanen et al. (1995) \\
\hline Jokioinen & 1 & 9 & 2000-01-01 & $2002-12-31$ & Regina et al. (2004) \\
\hline Kannus & 15 & 47 & 2000-01-01 & $2007-12-31$ & Maljanen et al. (2012) \\
\hline Kasesoo & 1 & 3 & 2009-01-01 & $2009-12-31$ & Salm et al. (2011) \\
\hline Kendlmühlfilze & 13 & 13 & 1999-01-01 & 1999-12-31 & $\begin{array}{l}\text { Drösler (2005), } \\
+ \text { unpublished data }\end{array}$ \\
\hline Kuresoo & 1 & 5 & 2009-01-01 & $2009-12-31$ & Salm et al. (2011) \\
\hline Kuuma & 1 & 9 & 2000-01-01 & $2002-12-31$ & Regina et al. (2004) \\
\hline Lakkasuo & 2 & 16 & 1991-01-01 & $1992-12-31$ & Laine et al. (1996) \\
\hline Linnansuo & 2 & 8 & 2004-01-01 & 2007-12-31 & Hyvönen et al. (2009) \\
\hline Ljubljana Marsh & 2 & 4 & 2005-01-01 & $2005-12-31$ & Danevčič et al. (2010) \\
\hline Lompolojaenkkae & 1 & 3 & 2006-01-01 & $2008-12-31$ & Lohila et al. (2010) \\
\hline Mooseurach & 18 & 33 & 2007-01-01 & 2011-12-31 & unpublished data \\
\hline Mørke & 1 & 3 & 2008-01-01 & $2008-12-31$ & Petersen et al. (2012) \\
\hline Nørreå & 1 & 1 & 2009-01-01 & $2009-12-31$ & unpublished data \\
\hline Orramossen & 1 & 1 & 2008-01-01 & $2008-12-31$ & Strömgren et al. (2014) \\
\hline Paulinenaue & 17 & 59 & 1995-01-01 & 2011-12-31 & $\begin{array}{l}\text { Augustin et al. (1998), } \\
\text { Bell et al. (2012), } \\
\text { Rees et al. (2013), } \\
\text { + unpublished data }\end{array}$ \\
\hline
\end{tabular}


Table 6. Continued.

\begin{tabular}{llllll}
\hline Name & $\begin{array}{l}\text { Number } \\
\text { of sites }\end{array}$ & $\begin{array}{l}\text { Number } \\
\text { of fluxes }\end{array}$ & Start date & End date & Reference \\
\hline Puhatu & 1 & 3 & $2009-01-01$ & $2009-12-31$ & Salm et al. (2011) \\
Reeiwijk & 1 & 3 & $2006-01-01$ & $2008-12-31$ & Kroon et al. (2010) \\
Rovaniemi & 1 & 6 & $2001-01-01$ & $2002-12-31$ & Regina et al. (2004) \\
Sangla & 1 & 1 & $2009-01-01$ & $2009-12-31$ & Salm et al. (2011) \\
Sernitz & 2 & 4 & $1998-01-01$ & $1999-12-31$ & ZALF unpublished data \\
Skjern & 1 & 2 & $2008-01-01$ & $2008-12-31$ & Petersen et al. (2012) \\
Spreewald & 4 & 8 & $2010-01-01$ & $2011-12-31$ & unpublished data \\
St. Vildmose & 1 & 3 & $2008-01-01$ & $2008-12-31$ & Petersen et al. (2012) \\
Valgeraba & 1 & 4 & $2009-01-01$ & $2009-12-31$ & Salm et al. (2011) \\
Vesijako & 8 & 8 & $2003-01-01$ & $2003-12-31$ & Minkkinen unpublished data \\
Westermoor & 8 & 16 & $2010-01-01$ & $2011-12-31$ & Beyer and Höper (2014), \\
& & & & & + unpublished data \\
Wildmoos & 2 & 4 & $2001-01-01$ & $2002-12-31$ & Jungkunst and Fiedler (2005) \\
Zarnekow & 5 & 21 & $2005-01-01$ & $2011-12-31$ & unpublished data \\
Zegveld & 6 & 27 & $1992-01-01$ & $2007-12-31$ & Velthof et al. (1996), \\
& & & & & Koops et al. (1997), \\
& & & & & van Beek et al. (2010) \\
\hline
\end{tabular}

uncertainty in the distribution functions of water table and bulk density contributes most to the total uncertainty estimation. The large forest areas in the boreal zone had the highest relative uncertainty but low $\mathrm{N}_{2} \mathrm{O}$ flux rates (Fig. 8).

The uncertainty of fluxes from natural sites was calculated by using the standard deviation $\left(0.27 \mathrm{~g} \mathrm{~N}_{2} \mathrm{O}-\mathrm{N} \mathrm{m}^{-2} \mathrm{a}^{-1}\right)$ of the distribution for all available $\mathrm{N}_{2} \mathrm{O}$ fluxes from natural sites.

\subsection{European $\mathrm{N}_{2} \mathrm{O}$ budget for organic soils}

The European $\mathrm{N}_{2} \mathrm{O}$ budget from organic soils has been calculated by the fuzzy model, the average emission factors (EFs) derived from the European observations and the IPCC approach. The budgets of these three approaches range between 149.5 and $87.4 \mathrm{Gg} \mathrm{N} 2{ }_{O}-\mathrm{N} \mathrm{a}^{-1}$ for the CLC land use data and between 132.7 and $121.1 \mathrm{Gg} \mathrm{N} 2 O_{-}-\mathrm{N} \mathrm{a}^{-1}$ for HILDA land use data (Table 4). The $95 \%$ confidence intervals (Table 4) indicate no distinct differences between the three flux estimates. The total $\mathrm{N}_{2} \mathrm{O}$ budget from organic soils is remarkably robust despite large differences in assumptions, underlying data and land use representation.

Only the fuzzy model is spatially explicit. The emissionfactor-based approaches assume that the observational basis is representative so that the mean observed flux represents the land use class. This assumption is obviously inadequate for $\mathrm{N}_{2} \mathrm{O}$ emissions from organic soils in Europe because the mean $\mathrm{N}_{2} \mathrm{O}$ emission by land use class calculated from the fuzzy model implied emission factor (IEF) deviates from the average EF of the underlying observations (Table 5). Clearly, forests and croplands with high $\mathrm{N}_{2} \mathrm{O}$ emissions and unfertilized grasslands with low $\mathrm{N}_{2} \mathrm{O}$ emissions are under-represented in European observations. Robust in- ventories should therefore strive for a good representation of driving parameters, in particular soil $\mathrm{pH}$ and $\mathrm{N}$ fertilization, which determine the high $\mathrm{N}_{2} \mathrm{O}$ emissions from cropland and grassland.

The IPCC EFs strongly disagree with the two Europebased IEFs. For forests, the low IPCC EF for boreal nutrientpoor forests seems too low for Europe, because if it is replaced with the EF for boreal nutrient-rich forests, then the forest $\mathrm{N}_{2} \mathrm{O}$ budget becomes similar to the results of the fuzzy model. The IPCC EF for cropland is between the fuzzy model IEF and the average EF. Additional measurements in the undersampled hotspot regions are, however, necessary in order to interpret these differences. The IPCC EF for grassland exceeds the Europe-based IEFs, but comes close if a reasonable fraction of shallow drained grassland is included. The IPCC EF for extraction sites is at the low end of European observations. This strongly points to missing hotspot observations in the worldwide IPCC database, which are partly included as unpublished data in our database. We conclude that the IPCC EF for extraction sites is not representative of Europe, while the EFs for forests, croplands and grasslands seem to match when the land stratification of nutrient status and drainage level is known.

The areas by land use class vary between CLC and HILDA due to differences in classification methods. Whereas forest areas represent approximately $50 \%$ of total peatland area in both classifications, crop- and grassland areas greatly differ due to different classifications. Natural and extraction sites are only available for the CLC land cover dataset. The land use differences provoke proportional differences in $\mathrm{N}_{2} \mathrm{O}$ budgets for croplands and grasslands. Nonetheless, the IEF derived from the spatially explicit fuzzy model remains rela- 
tively stable, and so the fuzzy model can be considered to yield robust IEFs independent of land use definitions. These IEFs would also qualify as national or Europe-wide tier 2 approach for GHG inventories. $\mathrm{N}_{2} \mathrm{O}$ emissions from organic soils represent up to $13 \%$ of total European $\mathrm{N}_{2} \mathrm{O}$ emissions reported in the EU GHG inventory of 2011 (European Commission, 2013) from only $7 \%$ of the $\mathrm{EU}$ area. $\mathrm{N}_{2} \mathrm{O}$ emissions from croplands alone on organic soils contribute 13 to $17 \%$ to the direct $\mathrm{N}_{2} \mathrm{O}$ emissions from agricultural used soils (European Commission, 2013).

\subsection{Anthropogenic $\mathrm{N}_{2} \mathrm{O}$ emissions}

Clearly, the $\mathrm{N}_{2} \mathrm{O}$ budget of organic soils is dominated by emissions from managed land use systems, in particular cropland and grassland. The natural background emission can be estimated by assuming that the total area of organic soils in Europe would be in pristine, natural condition. This natural baseline emission budget would amount to 21.53 (7.58-35.16) $\mathrm{Gg} \mathrm{N}_{2} \mathrm{O}-\mathrm{N} \mathrm{a}^{-1}$. The difference between these baseline emissions and the emission budget with realistic land use can be interpreted as the anthropogenic part of the $\mathrm{N}_{2} \mathrm{O}$ emissions budget. Accordingly, the anthropogenic contribution to $\mathrm{N}_{2} \mathrm{O}$ emissions amounts to 80 to $85 \%$ of the total European $\mathrm{N}_{2} \mathrm{O}$ budget.

\section{Conclusions}

We have compiled an extensive European dataset of $\mathrm{N}_{2} \mathrm{O}$ observations on organic soils, made a fuzzy model-based analysis of anthropogenic and natural drivers, and presented the first European spatially explicit $\mathrm{N}_{2} \mathrm{O}$ budget from organic soils. The total budget was consistent with inventories based on static emission factors provided that the emission factors were applied in a way that was representative of region- and land-use-specific emissions.

$\mathrm{N}_{2} \mathrm{O}$ emissions from organic soils are dominantly driven by human management, in particular the water table. Soil properties such as $\mathrm{C} / \mathrm{N}$ ratio, $\mathrm{pH}$ and bulk density modify the response strength of organic soils to human management. Climatic parameters such as seasonal or annual temperature and precipitation only have a secondary role in $\mathrm{N}_{2} \mathrm{O}$ emissions.

Organic soils in Europe emit more $\mathrm{N}_{2} \mathrm{O}$ than suggested by the IPCC default methodology. Less than $100000 \mathrm{~km}^{2}$ of agriculturally used organic soils emit about $80 \mathrm{Gg} \mathrm{N}_{2} \mathrm{O}$ $\mathrm{N} \mathrm{a}^{-1}$, equivalent to $20 \%$ of European direct soil $\mathrm{N}_{2} \mathrm{O}$ emissions from agriculture.

Acid croplands such as in Denmark or Poland, and intensively fertilized grasslands such as in the Netherlands or Germany were identified as the strongest hotspots. The hotspots from acid croplands are backed by only a few measurements and require further investigations.
Drainage is a main driver for $\mathrm{N}_{2} \mathrm{O}$ emissions, and therefore the groundwater table has been integrated into the model although it was not available for upscaling. This created additional uncertainty in the calculated regionalized $\mathrm{N}_{2} \mathrm{O}$ budget but also highlights that the largest source of uncertainty does not come from the $\mathrm{N}_{2} \mathrm{O}$ observations but from the uncertainty in spatial driver data. Improved spatial information on water table is critical for reducing uncertainty in inventories and targeting GHG mitigation measures. The sensitivity of $\mathrm{N}_{2} \mathrm{O}$ emissions on mean annual water table across land use classes indicates that water table management is one of the most effective ways to mitigate $\mathrm{N}_{2} \mathrm{O}$ emissions from land use of organic soils.

Acknowledgements. This study includes numerous unpublished datasets made available by several institutes. We gratefully thank all partners and PIs - Elisa Albiac Borraz, Sascha Beetz, Colja Beyer, Tim Eickenscheidt, Jan Heinichen, Wolfram Adelmann, JuliaMaria Hermann und Marika Bernrieder, Michael Sommer, Michael Giebels, Katharina Leiber-Sauheitl, Mandy Peichl-Brak, Holger Fell, Niko Rosskopf, Jutta Zeitz, and Christoph Förster - as well as involved institutes: the Weihenstephan-Triesdorf University of Applied Sciences, Freising; the Leibniz Centre for Agricultural Landscape Research, Müncheberg; the University of Rostock; the Humboldt University of Berlin; and the University of Hohenheim.

The research leading to these results received funding from the European Community's Seventh Framework Programme (FP7/2007-2013) under grant agreement no. 244122, from GHGEurope and from the German Federal Ministry of Education and Research (BMBF) within the project CCLandStraD (support code 01LL0909A). Furthermore, we acknowledge Andreas Laggner, Katrin Brautzsch, Michel Bechtold, Bärbel Tiemeyer and Ullrich Dettmann for data processing and expert knowledge support.

Edited by: P. Stoy

\section{References}

Arnold, K. V., Weslien, P., Nilsson, M., Svensson, B., and Klemedtsson, L.: Fluxes of $\mathrm{CO}_{2}, \mathrm{CH}_{4}$ and $\mathrm{N}_{2} \mathrm{O}$ from drained coniferous forests on organic soils, Forest Ecol. Manag., 210, 239-254, doi:10.1016/j.foreco.2005.02.031, 2005.

Augustin, J., Merbach, W., and Rogasik, J.: Factors influencing nitrous oxide and methane emissions from minerotrophic fens in northeast Germany, Biol. Fert. Soils, 28, 1-4, doi:10.1007/s003740050455, 1998.

Bardossy, A., Haberlandt, U., and Krysanova, V.: Automatic fuzzyrule assessment and its application to the modelling of nitrogen leaching for large regions, Soft Computing - A Fusion of Foundations, Methodol. Appl., 7, 370-385, - 2003.

Bechtold, M., Tiemeyer, B., Laggner, A., Leppelt, T., Frahm, E., and Belting, S.: Large-scale regionalization of water table depth in peatlands optimized for greenhouse gas emission upscaling, Hydrol. Earth Syst. Sci., 18, 3319-3339, doi:10.5194/hess-183319-2014, 2014. 
Beetz, S., Liebersbach, H., Glatzel, S., Jurasinski, G., Buczko, U., and Höper, H.: Effects of land use intensity on the full greenhouse gas balance in an Atlantic peat bog, Biogeosciences, 10, 1067-1082, doi:10.5194/bg-10-1067-2013, 2013.

Bell, M. J., Jones, E., Smith, J., Smith, P., Yeluripati, J., Augustin, J., Juszczak, R., Olejnik, J., and Sommer, M.: Simulation of soil nitrogen, nitrous oxide emissions and mitigation scenarios at 3 European cropland sites using the ECOSSE model, Nutr. Cycl. Agroecosys., 92, 161-181, doi:10.1007/s10705-011-94794, 2012.

Beyer, C. and Höper, H.: Greenhouse gas emissions from rewetted bog peat extraction sites and a Sphagnum cultivation site in Northwest Germany, Biogeosciences Discuss., 11, 4493-4530, doi:10.5194/bgd-11-4493-2014, 2014.

Büttner, G. and Kosztra, B.: CLC2006 technical guidelines, European Environment Agency, Technical Report, 1, 70 pp., 2007.

Chapuis-Lardy, L., Wrage, N., Metay, A., Chotte, J.-L., and Bernoux, M.: Soils, a sink for $\mathrm{N}_{2} \mathrm{O}$ ? A review, Glob. Change Biol., 13, 1-17, 2007.

Danevčič, T., Mandic-Mulec, I., Stres, B., Stopar, D., and Hacin, J.: Emissions of $\mathrm{CO}_{2}, \mathrm{CH}_{4}$ and $\mathrm{N}_{2} \mathrm{O}$ from Southern European peatlands, Soil Biol. Biochem., 42, 1437-1446, 2010.

Dechow, R. and Freibauer, A.: Assessment of German nitrous oxide emissions using empirical modelling approaches, Nutr. Cycl. Agroecosys., 91, 235-254, 2011.

Dobbie, K. E. and Smith, K. A.: Nitrous oxide emission factors for agricultural soils in Great Britain: the impact of soil water-filled pore space and other controlling variables, Glob. Change Biol., 9, 204-218, 2003.

Dobbie, K. E., McTaggart, I. P., and Smith, K. A.: Nitrous oxide emissions from intensive agricultural systems: Variations between crops and seasons, key driving variables, and mean emission factors, J. Geophys. Res., 104, 26891-26899, 1999.

Drösler, M.: Trace gas exchange and climatic relevance of bog ecosystems, southern Germany, Ph.D. thesis, 2005.

Eickenscheidt, T., Heinichen, J., Augustin, J., Freibauer, A., and Drösler, M.: Gaseous nitrogen losses and mineral nitrogen transformation along a water table gradient in a black alder (Alnus glutinosa (L.) Gaertn.) forest on organic soils, Biogeosciences Discuss., 10, 19071-19107, doi:10.5194/bgd-10-19071-2013, 2013.

Eickenscheidt, T., Freibauer, A., Heinichen, J., Augustin, J., and Drösler, M.: Short-term effects of biogas digestate and cattle slurry application on greenhouse gas emissions from high organic carbon grasslands, Biogeosciences Discuss., 11, 5765-5809, doi:10.5194/bgd-11-5765-2014, 2014.

European Commission: Annual European Union greenhouse gas inventory 1990-2011 and inventory report 2013, Tech. rep., European Commission, http://unfccc.int/files/national_reports/ annex_i_ghg_inventories/national_inventories_submissions/ application/zip/eua-2013-crf-27may.zip, 2013.

Firestone, M. K. and Davidson, E. A.: Microbiological basis of NO and $\mathrm{N}_{2} \mathrm{O}$ production and consumption in soil, vol. 47, John Wiley \& Sons, 1989.

Freibauer, A. and Kaltschmitt, M.: Controls and models for estimating direct nitrous oxide emissions from temperate and subboreal agricultural mineral soils in Europe, Biogeochemistry, 63, 93-115, 2003.
Fuchs, R., Herold, M., Verburg, P. H., and Clevers, J.: A highresolution and harmonized model approach for reconstructing and analysing historic land changes in Europe, Biogeosciences, 10, 1543-1559, doi:10.5194/bg-10-1543-2013, 2013.

Gebbert, S. and Pebesma, E.: TGRASS: A temporal GIS for field based environmental modeling, Environ. Modell. Softw., 53, 1-12, 2014.

Grønlund, A., Sveistrup, T. E., Søvik, A. K., Rasse, D. P., and Kløve, B.: Degradation of cultivated peat soils in northern norway based on field scale $\mathrm{CO}_{2}, \mathrm{~N}_{2} \mathrm{O}$ and $\mathrm{CH}_{4}$ emission measurements, Arch. Acker Pfl. Boden., 52, 149-159, doi:10.1080/03650340600581968, 2006.

Haylock, M. R., Hofstra, N., Tank, A. M. G. K., Klok, E. J., Jones, P. D., and New, M.: A European daily high-resolution gridded data set of surface temperature and precipitation for 1950-2006, J. Geophys. Res., 113, D20119, doi:10.1029/2008JD010201, 2008.

Hutchinson, G. L. and Mosier, A. R.: Improved Soil Cover Method for Field Measurement of Nitrous Oxide Fluxes, Soil Sci. Soc. Am. J., 45, 311-316, doi:10.2136/sssaj1981.03615995004500020017x, 1981.

Hutchings, N. J., Reinds, G. J., Leip, A., Wattenbach, M., Bienkowski, J. F., Dalgaard, T., Dragosits, U., Drouet, J. L., Durand, P., Maury, O., and de Vries, W.: A model for simulating the timelines of field operations at a European scale for use in complex dynamic models, Biogeosciences, 9, 4487-4496, doi:10.5194/bg-9-4487-2012, 2012.

Hyvönen, N., Huttunen, J., Shurpali, N., Tavi, N., Repo, M., and Martikainen, P.: Fluxes of nitrous oxide and methane on an abandoned peat extraction site: effect of reed canary grass cultivation, Bioresource Technol., 100, 4723-4730, doi:10.1016/j.biortech.2009.04.043, 2009.

IPCC: Supplement to the 2006 IPCC Guidelines for National Greenhouse Gas Inventories: Wetlands, Tech. rep., the national greenhouse gas inventories programme, 2013.

Jones, R. J. A., Hiederer, R., Rusco, E., and Montanarella, L.: Estimating organic carbon in the soils of Europe for policy support, Europ. J. Soil Sci., 56, 655-671, 2005.

Jungkunst, H. F. and Fiedler, S.: Geomorphology-key regulator of net methane and nitrous oxide fluxes from the pedosphere, $\mathrm{Z}$. Geomorphol., 49, 429-543, 2005.

Jungkunst, H. F., Freibauer, A., Neufeldt, H., and Bareth, G.: Nitrous oxide emissions from agricultural land use in Germany - a synthesis of available annual field data, J. Plant Nutrit. Soil Sci., 169, 341-351, 2006.

Klemedtsson, L., Klemedtsson, A. K., Moldan, F., and Weslien, P.: Nitrous oxide emission from Swedish forest soils in relation to liming and simulated increased N-deposition, Biol. Fertil. Soils, 25, 290-295, 1997.

Klemedtsson, A. K., Weslien, P., and Klemedtsson, L.: Methane and nitrous oxide fluxes from a farmed Swedish Histosol, Eur. J. Soil Sci., 60, 321-331, doi:10.1111/j.1365-2389.2009.01124.x, 2009.

Klemedtsson, L., Von Arnold, K., Weslien, P., and Gundersen, P.: Soil CN ratio as a scalar parameter to predict nitrous oxide emissions, Glob. Change Biol., 11, 1142-1147, 2005.

Kløve, B., Sveistrup, T. E., and Hauge, A.: Leaching of nutrients and emission of greenhouse gases from peatland cultivation at Bodin, Northern Norway, Geoderma, 154, 219-232, doi:10.1016/j.geoderma.2009.08.022, 2010. 
Kohavi, R.: A study of cross-validation and bootstrap for accuracy estimation and model selection, in: International joint Conference on artificial intelligence, 14, 1137-1145, 1995.

Koops, J., van Beusichem, M., and Oenema, O.: Nitrogen loss from grassland on peat soils through nitrous oxide production, Plant Soil, 188, 119-130, 1997.

Kroon, P., Vesala, T., and Grace, J.: Flux measurements of $\mathrm{CH}_{4}$ and $\mathrm{N}_{2} \mathrm{O}$ exchanges, Agr. Forest Meteorol., 150, 745-747, 2010.

Laine, J., Silvola, J., Tolonen, K., Alm, J., Nykänen, H., Vasander, H., Sallantaus, T., Savolainen, I., Sinisalo, J., and Martikainen, P. J.: Effect of water-level drawdown on global climatic warming: northern peatlands, Ambio, 25, 179-184, 1996.

Leiber-Sauheitl, K., Fuß, R., Voigt, C., and Freibauer, A.: High $\mathrm{CO}_{2}$ fluxes from grassland on histic Gleysol along soil carbon and drainage gradients, Biogeosciences, 11, 749-761, doi:10.5194/bg-11-749-2014, 2014.

Liu, B., Mørkved, P. T., Frostegård, Å., and Bakken, L. R.: Denitrification gene pools, transcription and kinetics of $\mathrm{NO}, \mathrm{N}_{2} \mathrm{O}$ and $\mathrm{N}_{2}$ production as affected by soil $\mathrm{pH}$, FEMS Microbiol. Ecol., 72, 407-417, 2010.

Lohila, A., Aurela, M., Hatakka, J., Pihlatie, M., Minkkinen, K., Penttilä, T., and Laurila, T.: Responses of $\mathrm{N}_{2} \mathrm{O}$ fluxes to temperature, water table and $\mathrm{N}$ deposition in a northern boreal fen, Europ. J. Soil Sci., 61, 651-661, 2010.

Maljanen, M., Liikanen, A., Silvola, J., and Martikainen, P. J.: Nitrous oxide emissions from boreal organic soil under different land-use, Soil Biol. Biochem., 35, 689-700, 2003.

Maljanen, M., Sigurdsson, B. D., Guomundsson, J., Óskarsson, H., Huttunen, J. T., and Martikainen, P. J.: Greenhouse gas balances of managed peatlands in the Nordic countries - present knowledge and gaps, Biogeosciences, 7, 2711-2738, doi:10.5194/bg7-2711-2010, 2010.

Maljanen, M., Shurpali, N., Hytönen, J., Mäkiranta, P., Aro, L., Potila, H., Laine, J., Li, C., and Martikainen, P. J.: Afforestation does not necessarily reduce nitrous oxide emissions from managed boreal peat soils, Biogeochemistry, 108, 199-218, doi:10.1007/s10533-011-9591-1, 2012.

Mander, U., Uuemaa, E., Kull, A., Kanal, A., Maddison, M., Soosaar, K., Salm, J.-O., Lesta, M., Hansen, R., Kuller, R., Harding, A., and Augustin, J.: Assessment of methane and nitrous oxide fluxes in rural landscapes, Landsc. Urban Plann., 98, 172-181, 2010.

Mäkiranta, P., Hytönen, J., Aro, L., Maljanen, M., Pihlatie, M., Potila, H., Shurpali, N. J., Laine, J., Lohila, A., Martikainen, P. J., and Minkkinen, K.: Soil greenhouse gas emissions from afforested organic soil croplands and cutaway peatlands, Boreal Environ. Res., 12, 159-175, 2007.

Martikainen, P. J., Nykanen, H., Crill, P., and Silvola, J.: Effect of a lowered water table on nitrous oxide fluxes from northern peatlands, Nature, 366, 51-53, 1993.

Montanarella, L., Jones, R. J. A., and Hiederer, R.: The distribution of peatland in Europe, Mires and Peatland, 1, 2006.

Mørkved, P. T., Dörsch, P., and Bakken, L. R.: The $\mathrm{N}_{2} \mathrm{O}$ product ratio of nitrification and its dependence on long-term changes in soil pH, Soil Biol. Biochem., 39, 2048-2057, 2007.

Mosier, A. R.: Soil processes and global change, Biol. Fertil. Soils, 27, 221-229, 1998.
Nash, J. E. and Sutcliffe, J. V.: River flow forecasting through conceptual models - Part I: A discussion of principles, J. Hydrol., 10, 282-290, 1970.

Neteler, M., Bowman, M. H., Landa, M., and Metz, M.: GRASS GIS: A multi-purpose open source GIS, Environ. Modell. Software, 31, 124-130, 2012.

Nykanen, H., Alm, J., Lang, K., Silvola, J., and Martikainen, P. J.: Emissions of $\mathrm{CH}_{4}, \mathrm{~N}_{2} \mathrm{O}$ and $\mathrm{CO}_{2}$ from a virgin fen and a fen drained for grassland in Finland, J. Biogeogr., 22, 351-357, 1995.

Ojanen, P., Minkkinen, K., Alm, J., and Penttilä, T.: Soil-atmosphere $\mathrm{CO}_{2}, \mathrm{CH}_{4}$ and $\mathrm{N}_{2} \mathrm{O}$ fluxes in boreal forestrydrained peatlands, Forest Ecol. Manag., 260, 411-421, doi:10.1016/j.foreco.2010.04.036, 2010.

Panagos, P., Van Liedekerke, M., Jones, A., and Montanarella, L.: European Soil Data Centre: Response to European policy support and public data requirements, Land Use Policy, 29, 329-338, 2012.

Peichl-Brak, M.: The Influence of Land Management on the Fluxes of Greenhouse Gases in Organic Soils, Universität Hohenheim, 2013.

Petersen, S. O., Hoffmann, C. C., Schäfer, C.-M., BlicherMathiesen, G., Elsgaard, L., Kristensen, K., Larsen, S. E., Torp, S. B., and Greve, M. H.: Annual emissions of $\mathrm{CH}_{4}$ and $\mathrm{N}_{2} \mathrm{O}$, and ecosystem respiration, from eight organic soils in Western Denmark managed by agriculture, Biogeosciences, 9, 403-422, doi:10.5194/bg-9-403-2012, 2012.

Pouliot, G., Wisner, E., Mobley, D., and Hunt, William, J.: Quantification of emission factor uncertainty, J. Air Waste Manage. Assoc., 62, 287-298, 2012.

R Development Core Team: R: A language and environment for statistical computing, ISBN 3-900051-07-0. R Foundation for Statistical Computing. Vienna, Austria, http://www.R-project.org, 2013.

Rees, R. M., Augustin, J., Alberti, G., Ball, B. C., Boeckx, P., Cantarel, A., Castaldi, S., Chirinda, N., Chojnicki, B., Giebels, M., Gordon, H., Grosz, B., Horvath, L., Juszczak, R., Kasimir Klemedtsson, ̊., Klemedtsson, L., Medinets, S., Machon, A., Mapanda, F., Nyamangara, J., Olesen, J. E., Reay, D. S., Sanchez, L., Sanz Cobena, A., Smith, K. A., Sowerby, A., Sommer, M., Soussana, J. F., Stenberg, M., Topp, C. F. E., van Cleemput, O., Vallejo, A., Watson, C. A., and Wuta, M.: Nitrous oxide emissions from European agriculture - an analysis of variability and drivers of emissions from field experiments, Biogeosciences, 10, 2671-2682, doi:10.5194/bg-10-2671-2013, 2013.

Regina, K., Nykänen, H., Silvola, J., and Martikainen, P. J.: Fluxes of nitrous oxide from boreal peatlands as affected by peatland type, water table level and nitrification capacity, Biogeochemistry, 35, 401-418, 1996.

Regina, K., Syväsalo, E., Hannukkala, A., and Esala, M.: Fluxes of $\mathrm{N}_{2} \mathrm{O}$ from farmed peat soils in Finland, Europ. J. Soil Sci., 55, 591-599, 2004.

Reuter, H. I., Lado, L. R., Hengl, T., and Montanarella, L.: Continental-scale digital soil mapping using European soil profile data: soil pH, Hamburger Beiträge zur Physischen Geographie und Landschaftsökologie, 19, 91-102, 2008.

Roelandt, C., Van Wesemael, B., and Rounsevell, M.: Estimating annual $\mathrm{N}_{2} \mathrm{O}$ emissions from agricultural soils in temperate climates, Glob. Change Biol., 11, 1701-1711, 2005. 
Salm, J. O., Maddison, M., Tammik, S., Soosaar, K., Truu, J., and Mander, $\mathrm{U}$.: Emissions of $\mathrm{CO}_{2}, \mathrm{CH}_{4}$ and $\mathrm{N}_{2} \mathrm{O}$ from undisturbed, drained and mined peatlands in Estonia, Hydrobiologia, 692, 1-15, 2011.

Skiba, U. and Smith, K. A.: Nitrification and denitrification as sources of nitric oxide and nitrous oxide in a sandy loam soil, Soil Biol. Biochem., 25, 1527-1536, 1993.

Skiba, U., Sheppard, L., Macdonald, J., and Fowler, D.: Some key environmental variables controlling nitrous oxide emissions from agricultural and semi-natural soils in Scotland, Atmos. Environ., 32, 3311-3320, 1998.

Sozanska, M., Skiba, U., and Metcalfe, S.: Developing an inventory of $\mathrm{N}_{2} \mathrm{O}$ emissions from British soils, Atmos. Environ., 36, 987-998, 2002.

Strömgren, M., Fröberg, M., and Olsson, M.: Greenhouse gas fluxes from four drained forested peatlands with different fertility in southern Sweden, Boreal Environ. Res., in review, 2014.

Tauchnitz, N., Brumme, R., Bernsdorf, S., and Meissner, R.: Nitrous oxide and methane fluxes of a pristine slope mire in the German National Park Harz Mountains, Plant Soil, 303, 131-138, 2008.

Tiktak, A., Nie, D. D., Van Der Linden, T., and Kruijne, R.: Modelling the leaching and drainage of pesticides in the Netherlands: the GeoPEARL model, Agronomie, 22, 373-387, 2002. van Beek, C., Pleijter, M., Jacobs, C., Velthof, G., van Groenigen, J., and Kuikman, P.: Emissions of $\mathrm{N}_{2} \mathrm{O}$ from fertilized and grazed grassland on organic soil in relation to groundwater level, Nutr. Cycl. Agroecosys., 86, 331-340, 2010.

Velthof, G. and Oenema, O.: Nitrous oxide fluxes from grassland in the Netherlands: II. Effects of soil type, nitrogen fertilizer application and grazing, Europ. J. Soil Sci., 46, 541-549, 1995.

Velthof, G. L., Brader, A. B., and Oenema, O.: Seasonal variations in nitrous oxide losses from managed grasslands in the Netherlands, Plant Soil, 181, 263-274, doi:10.1007/BF00012061, 1996.

Weslien, P., Klemedtsson, A. K., Börjesson, G., and Klemedtsson, L.: Strong $\mathrm{pH}$ influence on $\mathrm{N}_{2} \mathrm{O}$ and $\mathrm{CH}_{4}$ fluxes from forested organic soils, Europ. J. Soil Sci., 60, 311-320, 2009.

Wild, Klemisch, and Pfadenhauer: Nitrous oxide and methane fluxes from organic soils under agriculture, Europ. J. Soil Sci., 49, 327-335, 1998.

Yamulki, S., Anderson, R., Peace, A., and Morison, J. I. L.: Soil $\mathrm{CO}_{2} \mathrm{CH}_{4}$ and $\mathrm{N}_{2} \mathrm{O}$ fluxes from an afforested lowland raised peatbog in Scotland: implications for drainage and restoration, Biogeosciences, 10, 1051-1065, doi:10.5194/bg-10-1051-2013, 2013. 